U.S. Department of the Interior

U.S. Geological Survey

In cooperation with the

Idaho Division of Environmental Quality and

Lower Boise River Water Quality Plan, Inc.

\title{
Water-Quality Conditions of the Lower Boise River, Ada and Canyon Counties, Idaho, May 1994 Through February 1997
}




\section{Water-Quality Conditions of the Lower Boise River, Ada and Canyon Counties, Idaho, May 1994 Through February 1997}

By William H. Mullins

Water-Resources Investigations Report 98-4111

In cooperation with the

Idaho Division of Environmental Quality and

Lower Boise River Water Quality Plan, Inc.

Boise, Idaho

1998 


\section{U.S. DEPARTMENT OF THE INTERIOR}

BRUCE BABBITT, Secretary

\section{U.S. GEOLOGICAL SURVEY}

Thomas J. Casadevall, Acting Director

Any use of firm, trade, and brand names in this report is for identification purposes only and does not constitute endorsement by the U.S. Government.

Additional information can be obtained from:

\section{District Chief}

U.S. Geological Survey

230 Collins Road

Boise, ID 83702-4520

http://idaho.usgs.gov
Copies of this report can be purchased from:

U.S. Geological Survey

Information Services

Box 25286

Federal Center

Denver, CO 80225

e-mail: infoservices@usgs.gov 


\section{CONTENTS}

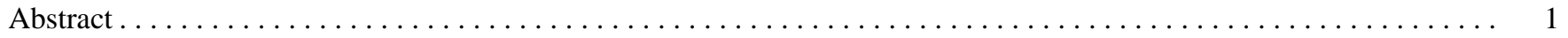

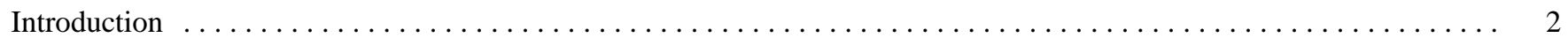

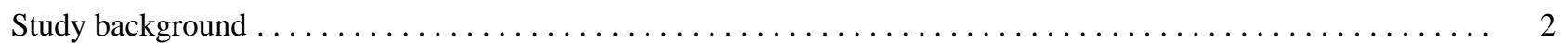

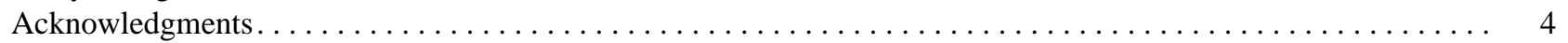

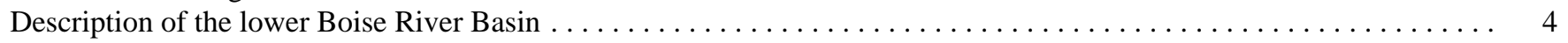

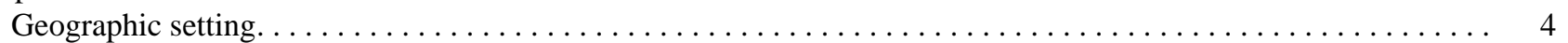

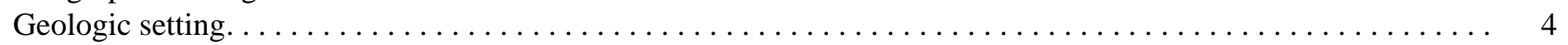

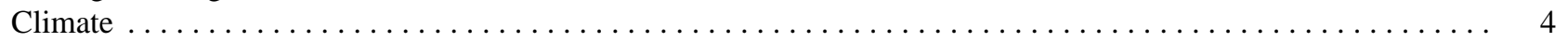

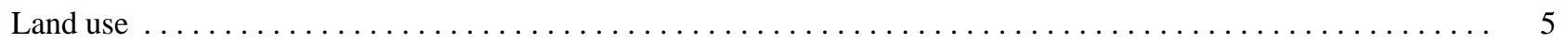

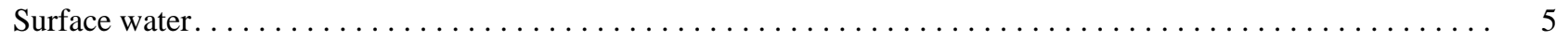

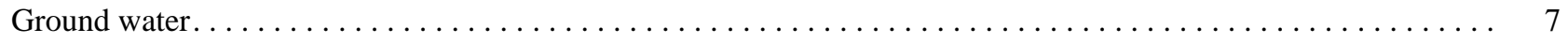

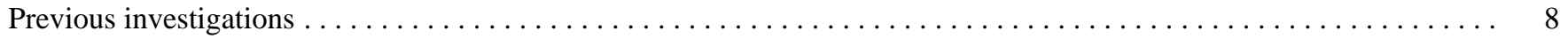

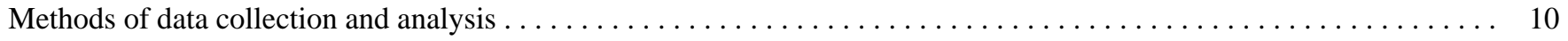

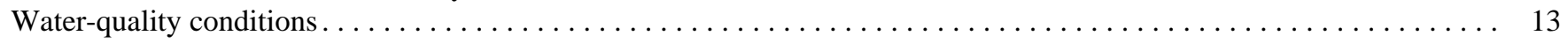

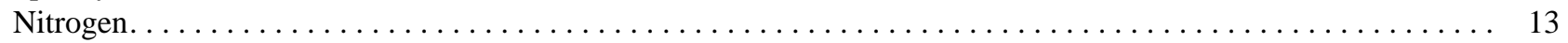

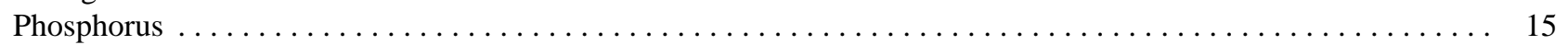

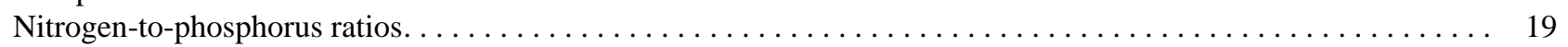

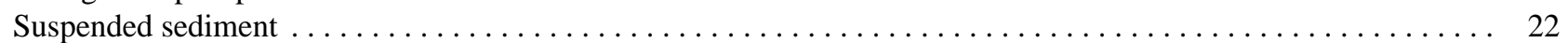

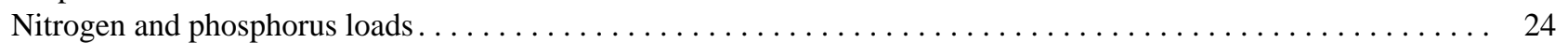

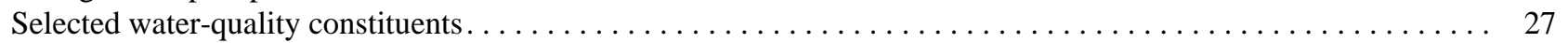

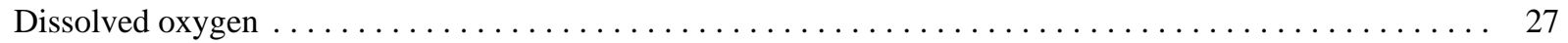

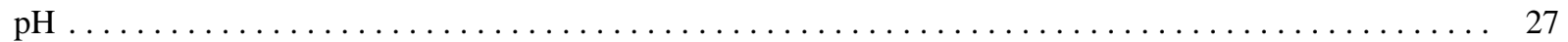

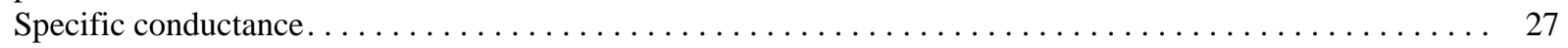

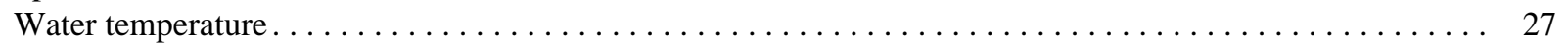

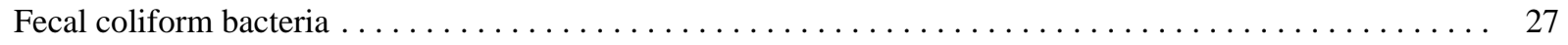

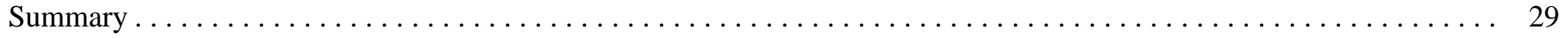

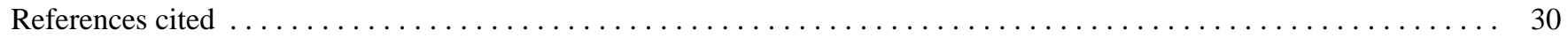

\section{FIGURES}

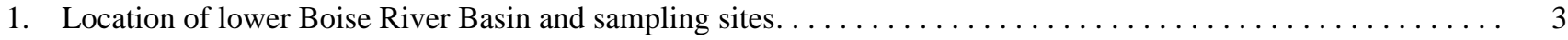

2. Schematic diagram of diversions, drains, and tributaries along the Boise River from Lucky Peak Lake

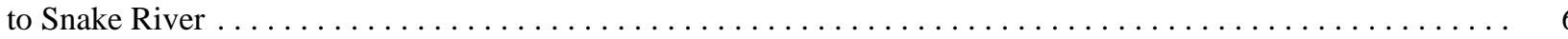

3. Graphs showing annual mean discharge and mean monthly discharge in the Boise River near Parma,

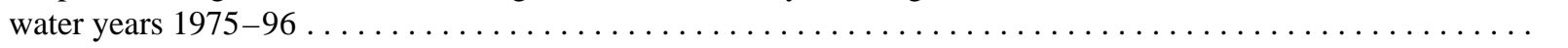

4. Graphs showing discharges at which water-quality samples were collected at Boise River sites, May 1994 through February 1997

5. Boxplots showing instantaneous concentrations and daily loads of total nitrogen in samples from 19 sites in the lower Boise River Basin, May 1994 through February $1997 \ldots \ldots \ldots \ldots \ldots \ldots \ldots$

6. Boxplots showing instantaneous concentrations and daily loads of dissolved inorganic nitrogen in samples from 19 sites in the lower Boise River Basin, May 1994 through February 1997 . . . . . . . . . . . . . . . . .

7. Graphs showing time series and trend line of concentrations of total nitrogen and dissolved inorganic nitrogen in samples from the Boise River near Parma, June 1974 through February 1997 . . . . . . . . . . . . .

8. Boxplots showing instantaneous concentrations and daily loads of total phosphorus in samples from 19 sites in the lower Boise River Basin, May 1994 through February $1997 \ldots \ldots \ldots \ldots \ldots \ldots \ldots \ldots$

9. Boxplots showing instantaneous concentrations and daily loads of dissolved orthophosphorus in samples from 19 sites in the lower Boise River Basin, May 1994 through February 1997 . . . . . . . . . . . . . . . . .

10. Graphs showing time series and trend line of concentrations of total phosphorus and dissolved orthophosphorus in samples from the Boise River near Parma, June 1974 through February 1997 . . . . . . . . . . . . .

11. Boxplots showing mass ratios of dissolved inorganic nitrogen to dissolved orthophosphorus, grouped by Boise River sites, May 1994 through February 1997 
12. Boxplots showing instantaneous concentrations and daily loads of suspended sediment in samples from 19 sites in the lower Boise River Basin, May 1994 through February $1997 \ldots \ldots \ldots \ldots \ldots \ldots \ldots \ldots \ldots \ldots \ldots . . \ldots 23$

13. Graphs showing time series and trend line of concentrations of suspended sediment in samples from the Boise River near Parma, June 1974 through February 1997 . . . . . . . . . . . . . . . . . . . . . . . . . . . 25

14. Graphs showing discharge and nutrient loads entering the Boise River from wastewater treatment facilities and tributary/drains during four synoptic sampling rounds, November 1994 through May 1996 . . . . . . . . 26

15. Boxplots showing concentrations of selected water-quality constituents in samples from 16 sites in the lower Boise River Basin, May 1994 through February $1997 \ldots \ldots \ldots \ldots \ldots \ldots \ldots \ldots \ldots \ldots \ldots \ldots \ldots$

16. Graph showing daily mean water temperatures at five Boise River sites between July 18 and September 5, 1996

\section{TABLES}

1. Means and ranges for selected water-quality constituents reported by the Bureau of Reclamation in 1977 for sites in the lower Boise River Basin that correspond with sites measured by the U.S. Geological

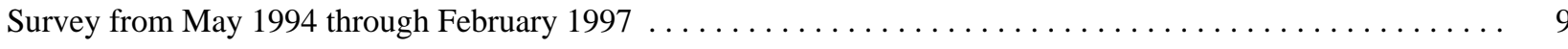

2. Water-quality constituents analyzed in samples from sites in the lower Boise River Basin, May 1994

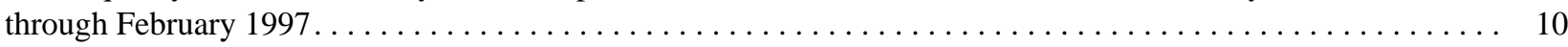

3. Locations of sampling sites, types of samples collected, and collection frequency, lower Boise River Basin,

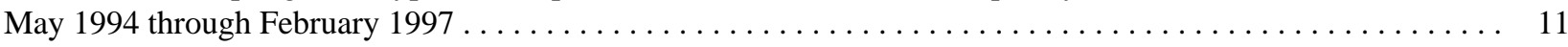

4. Statistical summary of total nitrogen concentrations and instantaneous loads in samples from sites in the lower Boise River Basin, May 1994 through February $1997 \ldots \ldots \ldots \ldots \ldots \ldots \ldots \ldots \ldots \ldots \ldots \ldots \ldots$

5. Statistical summary of total phosphorus concentrations and instantaneous loads in samples from sites in the lower Boise River Basin, May 1994 through February 1997 . . . . . . . . . . . . . . . . . . . . . . . . . . . 19

6. Statistical summary of suspended sediment concentrations and instantaneous loads in samples from sites in the lower Boise River Basin, May 1994 through February $1997 \ldots \ldots \ldots \ldots \ldots \ldots \ldots \ldots \ldots \ldots \ldots \ldots$. . . . . . . . . .

\section{CONVERSION FACTORS, VERTICAL DATUM, AND ABBREVIATED WATER-QUALITY UNITS}

\begin{tabular}{rcl}
\hline Multiply & By & To obtain \\
\hline acre & 4,047 & square meter \\
acre-foot $(\mathrm{acre}-\mathrm{ft})$ & 1,233 & cubic meter \\
foot $(\mathrm{ft})$ & 0.02832 & cubic meter per second \\
cubic foot per second $\left(\mathrm{ft}^{3} / \mathrm{s}\right)$ & 0.3048 & meter \\
foot per mile $(\mathrm{ft} / \mathrm{mi})$ & 0.1894 & meter per kilometer \\
inch (in.) & 2.54 & centimeter \\
mile (mi) & 1.609 & kilometer \\
pound (lb) & 0.4536 & kilogram \\
pound per day (lb/d) & 0.4536 & kilogram per day \\
square mile (mi $\left.{ }^{2}\right)$ & 2.590 & square kilometer \\
ton per day (ton/d) & 907.2 & kilogram per day \\
\hline
\end{tabular}

To convert ${ }^{\circ} \mathrm{C}$ (degrees Celsius) to ${ }^{\circ} \mathrm{F}$ (degrees Fahrenheit), use the following equation:

$$
{ }^{\circ} \mathrm{F}=\left(1.8^{\circ} \mathrm{C}\right)+32
$$

Sea level: In this report, "sea level" refers to the National Geodetic Vertical Datum of 1929—a geodetic datum derived from a general adjustment of the first-order level nets of the United States and Canada, formerly called Sea Level Datum of 1929. 


\section{Abbreviated water-quality units:}

$\mu \mathrm{g} / \mathrm{L} \quad$ micrograms per liter

$\mu \mathrm{m} \quad$ micrometer

$\mu \mathrm{S} / \mathrm{cm} \quad$ microsiemens per centimeter at $25^{\circ} \mathrm{C}$

$\mathrm{mg} / \mathrm{L} \quad$ milligrams per liter

$\mathrm{mL} \quad$ milliliter

\section{EXPLANATION OF BOXPLOTS}

(Figures 5, 6, 8, 9, 11, 12, 15)

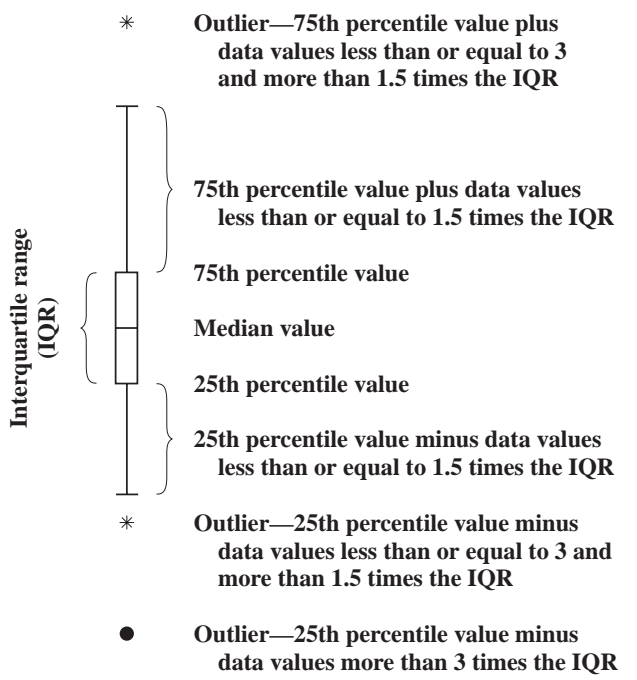




\title{
WATER-QUALITY CONDITIONS OF THE LOWER BOISE RIVER, ADA AND CANYON COUNTIES, IDAHO, MAY 1994 THROUGH FEBRUARY 1997
}

\author{
By William H. Mullins
}

\section{Abstract}

Agricultural land and water use, wastewater treatment facility discharges, land development, road construction, urban runoff, confined-animal feeding operations, reservoir operations, and river channelization affect the water quality and biotic integrity of the lower Boise River between Lucky Peak Dam and the river's mouth at Parma, Idaho. During May 1994 through February 1997, 4 sites on the Boise River, 12 tributary/drain sites, and 3 wastewater treatment facilities were sampled at various intervals during the irrigation (high-flow) and post-irrigation (low-flow) seasons to determine sources, concentrations, and relative loads of nutrients and suspended sediment. Discharge entering the Boise River from the 12 tributary/drain sites and 3 wastewater treatment facilities was measured to determine the nutrient loads being contributed from each source.

Total nitrogen, total phosphorus, and suspended sediment concentrations and loads tended to increase in a downstream direction along the Boise River. Among the 15 sources of discharge to the Boise River, 3 southside tributary/drains and the West Boise wastewater treatment facility contributed the largest loads of total nitrogen; the median daily load was more than 2,000 pounds per day. The West Boise wastewater treatment facility contributed the largest median daily load of total phosphorus (810 pounds per day); Dixie Drain contrib- uted the largest median daily load of suspended sediment (26.4 tons per day).

Nitrogen-to-phosphorus ratios at the four Boise River sites indicated that phosphorus could be limiting algal growth at the Diversion Dam site, whereas nitrogen could be limiting algal growth at the Glenwood and Middleton sites during some parts of the year. Algal growth in the Boise River near Parma did not appear to be nutrient limited.

Because of the complexity of the plumbing system in the lower Boise River (numerous diversions and inflow points), accurate comparisons between discharge and nutrient loads entering the river at measured sites during high-flow sampling periods were difficult. During low-flow sampling periods, southside tributary/drains contributed most of the discharge and total nitrogen load, and wastewater treatment facilities contributed most of the total phosphorus load to the Boise River.

During the 50-day period July 18 through September 5, 1996, the Idaho State standard for maximum daily average temperature for coldwater biota was exceeded by 34 percent at Middleton, 48 percent at Caldwell, and 80 percent near Parma. Violations of State standards for primary and secondary contact recreation were observed at all tributary/drains and in the Boise River near Parma. Median instantaneous concentrations of fecal coliform bacteria exceeded State standards for primary contact recreation at five tributary/drains and exceeded 
standards for secondary contact recreation at one tributary/drain (Dixie Drain).

\section{INTRODUCTION}

Agricultural land and water uses, wastewater treatment facility (WTF) discharges, land development, road construction, urban runoff, and confined-animal feeding operations (CAFOs), coupled with reservoir operations and river channelization, affect water quality and biotic integrity of the lower Boise River. The Boise River between Lucky Peak Dam at river mile (RM) 64 and Eagle Island at RM 42 (fig. 1) is affected primarily by effluent from surrounding urban communities. The river between Eagle Island and the confluence with the Snake River is affected primarily by irrigation diversions and return flows, CAFOs, and other small municipal effluent discharges and urban runoff. These land- and water-use activities affect streamflow in the river, increase nutrient and sediment concentrations and loads, bacteria levels, and water temperatures.

Studies conducted by the Idaho Department of Health and Welfare (1989, p. 54) documented that the lower Boise River only partially supported the designated beneficial uses of coldwater biota, salmonid spawning, and primary and secondary contact recreation. Later studies documented continued declines in water quality (Idaho Department of Health and Welfare, 1992, p. 7). In October 1994, the lower Boise River was listed as water-quality limited in accordance with paragraph 303(d) of the Clean Water Act (U.S. Environmental Protection Agency, 1994, p. 6). This listing required the State of Idaho to develop total maximum daily loads (TMDLs) for the lower Boise River. The reaches from the Snake River to Star (RMs 0 to 34) were assigned a high-priority ranking, whereas the reaches from Star to Lucky Peak Lake (RMs 34 to 64) were assigned a lowpriority ranking. Constituents of concern in these reaches that must be addressed in a TMDL include nutrients, suspended sediment, bacteria, elevated water temperature, low dissolved-oxygen concentrations, oil and grease, and flow modification. The TMDL is being developed and is scheduled for completion in 1998.

\section{Study Background}

The Lower Boise River Water Quality Plan, Inc. (LBRWQP), composed of public and private agencies, groups, and individuals, identified a need to assess current water-quality conditions of the lower Boise River. The LBRWQP was established in 1992 to (1) identify areas in the basin that contribute high nutrient and suspended sediment concentrations and loads, (2) initiate voluntary water-quality management practices, and (3) monitor the long-term effectiveness of these practices on the water quality and biotic integrity of the lower Boise River.

To assess the existing water quality and biotic integrity of the Boise River and to provide a baseline from which to assess future trends, the U.S. Geological Survey (USGS) began an 8-year comprehensive assessment of the river in 1994. The study is cooperatively funded by the Idaho Division of Environmental Quality (IDEQ), LBRWQP, and USGS.

The three primary objectives of this investigation are to (1) describe chemical and biological conditions of the river and its tributaries and drains, (2) assess the biotic integrity of the river, and (3) monitor the long-term water-quality trends and biotic integrity of the river.

The study is being implemented in three phases. Phase 1 consisted of synoptic sampling (samples collected at 4 main-stem river sites and 12 tributary/agricultural drain sites) to assess the quality and quantity of irrigation return flows during the irrigation season and the ground-water seepage after the irrigation season. The phase 1 data were used to determine the major sources, concentrations, and relative loads of nutrients and suspended sediment and to select long-term monitoring sites and sampling frequency. Phase 1 synoptic sampling was conducted during the first two study years (April 1994 through March 1996), in May (irrigation season) and November (post-irrigation season).

Phase 2 consisted of long-term water-quality monitoring and aquatic biological assessment activities and overlapped the second year of phase 1. Phase 2 activities included 2 years of intensive interval water-quality sampling, continuation of the two annual synoptic sampling rounds, and initiation of semiquantitative aquatic biological and habitat assessment. Interval sampling consisted of measuring the quantity and quality of water at four main-stem river sites and eight tributary/drains every other month, and one extra round of sampling during spring runoff, at the beginning of the irrigation season.

Annual synoptic and interval water-quality sampling and semiquantitative aquatic biological and habitat assessment will continue in the 5-year phase 3 of the study, beginning in April 1997. Phase 3 interval sam- 


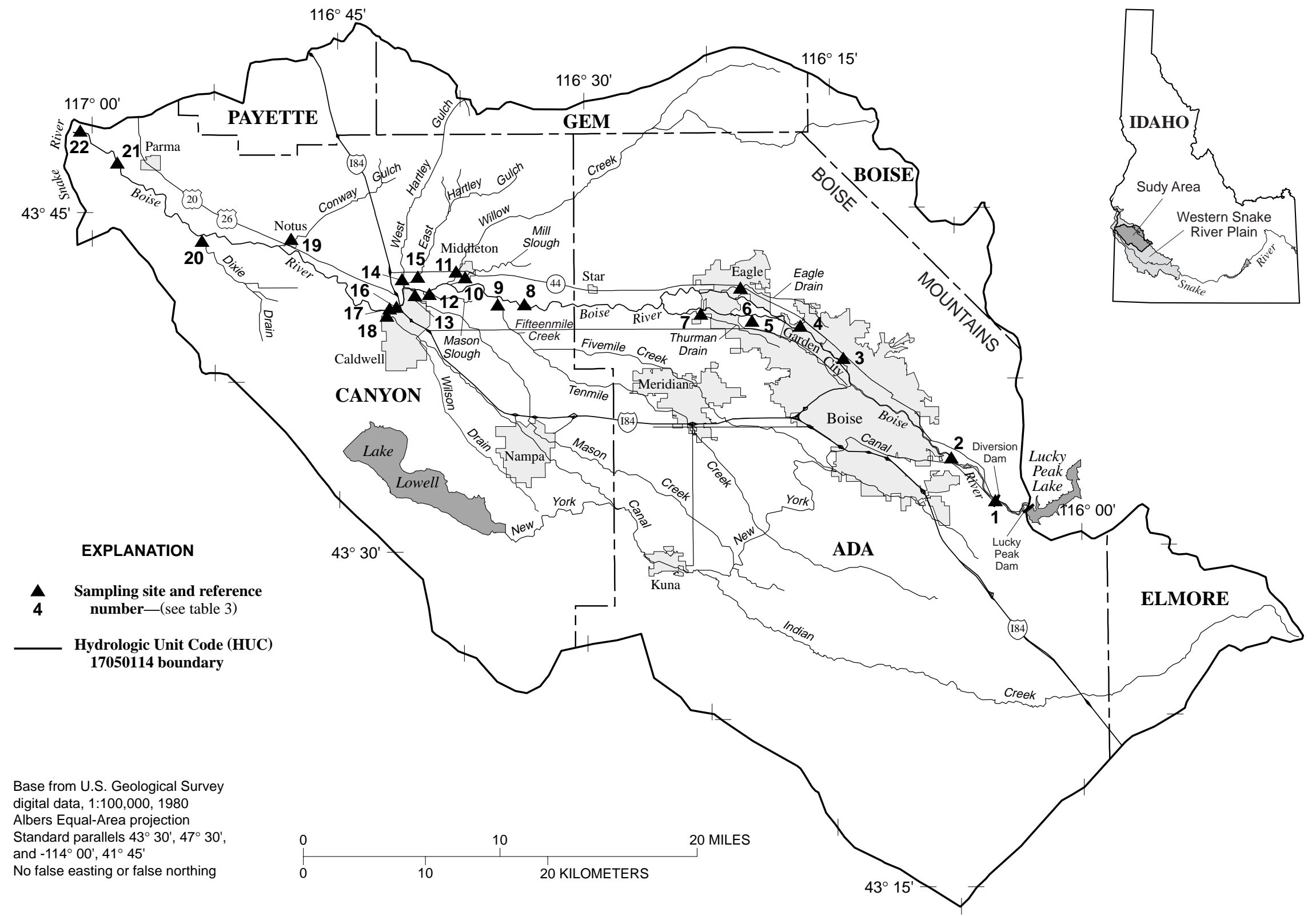

Figure 1. Location of lower Boise River Basin and sampling sites. 
pling will be conducted at the same frequency as in phase 2 , but only at the four main-stem sites.

This report summarizes chemical data collected during phases 1 and 2 of the study and describes the water-quality conditions of the river and its tributaries and drains.

\section{Acknowledgments}

The author wishes to express appreciation to the following staff of the USGS Idaho District Office and Boise Field Office for assistance in field work, data management, and advice: Michael Beckwith, Gregory Clark, Amber Erickson, Steve Garcia, David George, Walton Low, Terry Maret, Susan Moore, Sabrina Nicholls, Ivalou O'Dell, Doug Ott, Tomas Puga, Alvin Sablan, Jim Schaefer, and Paul Woods. Special thanks go to Greg Clark, who drafted the sections of this report on nitrogen-to-phosphorus ratios and synoptic estimates of loads and prepared most of the figures.

\section{DESCRIPTION OF THE LOWER BOISE RIVER BASIN}

\section{Geographic Setting}

The 1,290-mi ${ }^{2}$ lower Boise River Basin is located in Ada and Canyon Counties in southwestern Idaho between Lucky Peak Lake (RM 64) and the confluence of the Boise and Snake Rivers (fig. 1). The basin contains the most industrialized and urbanized areas in Idaho. The 1990 population of 296,000 in Ada and Canyon Counties constitutes about 29 percent of Idaho's total population.

The lower Boise River Basin is in the northern part of the western Snake River Plain. The southern boundary of the lower basin is a low ridge south of Indian Creek. Other basin boundaries are formed by a low ridge above the Snake River to the west, the Boise Mountains to the northeast, and a low ridge of foothills to the north. The upper basin upstream from Lucky Peak Lake is mountainous and sparsely populated. In addition to the Boise River, the study area is drained by several tributaries interconnected with a complex irrigation system of canals, laterals, and drains.

\section{Geologic Setting}

The lower Boise River lies in a broad, alluviumfilled basin with several steplike terraces, or benches, which are more pronounced and continuous on the south side of the river. Downstream from Lucky Peak Lake, the basin floor slopes northwestward at a gradient of about $10 \mathrm{ft} / \mathrm{mi}$. The altitude of the basin near Lucky Peak Lake is about 2,800 ft above sea level; the altitude near the river mouth is about 2,200 ft (Thomas and Dion, 1974, p. 7).

The flood plain of the Boise River and some of the larger tributaries consists of unconsolidated alluvium (silt, sand, and coarse, well-sorted gravel) as much as about $50 \mathrm{ft}$ thick. This layer is covered with a mantle of soil as much as $20 \mathrm{ft}$ thick. River terraces north and south of the Boise River are composed of unconsolidated clay, silt, sand, and well-sorted gravel containing gravel and cobbles from the Idaho batholith and Snake River Group. These deposits are as much as $100 \mathrm{ft}$ thick. Flows of vesicular olivine basalt as much as $300 \mathrm{ft}$ thick belonging to the Snake River Group crop out southeast of Boise and north of Caldwell (Thomas and Dion, 1974, p. 12), forming cliffs above the river between Diversion and Lucky Peak Dams and north of Caldwell.

Older terrace gravel, consisting of unconsolidated silt, sand, and well-sorted gravel beds about $150 \mathrm{ft}$ thick, and rocks of the Glenns Ferry Formation, composed mainly of unconsolidated deposits of clay, silt, sand, and fine gravel about 2,000 ft thick, underlie most of the lower Boise River Basin. The basement rock probably consists of granitic rocks of the Idaho batholith, which formed a deep trough in which younger rocks were deposited (Thomas and Dion, 1974, p. 11-12).

\section{Climate}

Climate in the lower Boise River Basin is characterized as semiarid; winters are cool and wet, and summers are warm and dry. Area climate is controlled primarily by the general atmospheric circulation over the northern Pacific Ocean. In the summer, subtropical air from the Pacific Ocean and Gulf of Mexico circulates northward, resulting in high temperatures and generally dry conditions, although sporadic thunderstorms cause small amounts of precipitation. During the fall and winter, air movements shift to a westerly flow from the Pacific Ocean, and most precipitation develops from frontal systems passing through the area. During the relatively wet spring months (March-May), a combination of 
thunderstorms and frontal systems produces nearly onethird of the annual precipitation. Mean annual precipitation as measured by the National Weather Service at the Boise airport during 1951-93 was about 11.9 in.

\section{Land Use}

Land use in the lower Boise River Basin consists primarily of irrigated and nonirrigated agriculture and related uses and urban activities. Land use in the upper Boise River Basin consists primarily of logging and recreation. Historically, parts of the upper basin have been heavily mined for gold by using shaft- and placer-mining methods.

Land use in the lower Boise River Basin has undergone major shifts in recent decades. Significant population growth has resulted in the conversion of large tracts of farmland to residential subdivisions and commercial facilities, and many residential areas within and adjacent to cities have been replaced with businesses, shopping centers, and parking lots, resulting in an increase in stormwater runoff into the Boise River and its tributaries (Kjelstrom, 1995, p. 1).

\section{Surface Water}

Flow in the Boise River between Lucky Peak Dam and the mouth is controlled primarily by reservoir regulation, irrigation withdrawals, irrigation return flows, and seepage of shallow ground water (Thomas and Dion, 1974, p. 4). Lucky Peak Lake (fig. 1) and Arrowrock and Anderson Ranch Reservoirs (about 7 mi east, and about 30 mi southeast, respectively, of Lucky Peak Lake) in the upper Boise River Basin are managed primarily for irrigation and flood control and secondarily for recreation and power generation. These reservoirs and lake have a combined storage capacity of about 1.06 million acre-ft and supply irrigation water to about 350,000 acres in the lower Boise River Basin. Lake Lowell (fig. 1) stores water diverted from the Boise River at Diversion Dam east of Boise. Thirty diversions divert water from the Boise River and Payette River for irrigation, and 12 major irrigation tributary/drains discharge to the Boise River between Lucky Peak Lake and the mouth (fig. 2). Water diverted from the Payette River at Black Canyon Dam through the Black Canyon, CLine, and D-Line Canal complex is used to irrigate lands on the north side of the Boise River and ultimately flows into the Boise River through several northside tributary/drains (Naylor and others, 1976, p. 4-5; Ingham, 1993, p. 2). (The Payette River parallels the Boise River about 10 mi to the north. Black Canyon Dam on the Payette River is located about 15 mi north of Eagle. Water pumped from the Black Canyon Canal enters the lower Boise River Basin through the C-Line and D-Line Canal complex about $13 \mathrm{mi}$ north of Caldwell.)

Flood-control releases from Lucky Peak Lake in the spring result in high streamflows (fig. 3) that persist all the way to the Snake River. However, in years of severe and (or) consecutive drought, such as those in the late 1980 's to early 1990's, late-winter and spring flows remain low except for short periods of time. In wet years, such as those in the early 1980's and during 1995-96, high flows can last from December or January through June. Irrigation releases typically begin in mid-April (or following flood releases) and continue through midOctober. Although relatively high streamflows are released from Lucky Peak Lake, streamflow progressively diminishes downstream to a low point in the Star-Middleton reach as many irrigation diversions extract water from the river. Downstream from Middleton, streamflow again increases as a result of irrigation return flows and seepage of shallow ground water. During the winter, minimum flows of about $150 \mathrm{ft}^{3} / \mathrm{s}$ usually are released from Lucky Peak Lake to maintain fish habitat and dilute effluent from WTFs. Flows in the river increase steadily downstream as a result of ground-water seepage and tributary inflow. Thomas and Dion (1974, p. 39) estimated that surface drains contributed about 80 percent of the total inflow to the Boise River downstream from Lucky Peak Dam, and that about 60 percent of this inflow entered the river in the 20-mi reach between Star (RM 44) and Notus (RM 14.)

Mean annual flow during 1955-96 was 2,280 $\mathrm{ft}^{3} / \mathrm{s}$ $(2,014,000 \mathrm{acre}-\mathrm{ft} / \mathrm{yr})$ at the gaging station on the Boise River downstream from Lucky Peak Lake (Brennan and others, 1997). Mean annual flow during 1982-96 was $1,198 \mathrm{ft}^{3} / \mathrm{s}(868,100$ acre- $\mathrm{ft} / \mathrm{yr})$ at the gaging station on the Boise River at Glenwood Bridge, downstream from several major diversions (Brennan and others, 1997). Mean annual discharge during 1971-96 was $1,628 \mathrm{ft}^{3} / \mathrm{s}$ $(1,179,000$ acre-ft/yr) at the gaging station near Parma near the mouth of the Boise River. Annual mean discharge and mean monthly discharge during 1975-96 for the gaging station on the Boise River near Parma are shown in figure 3 . 

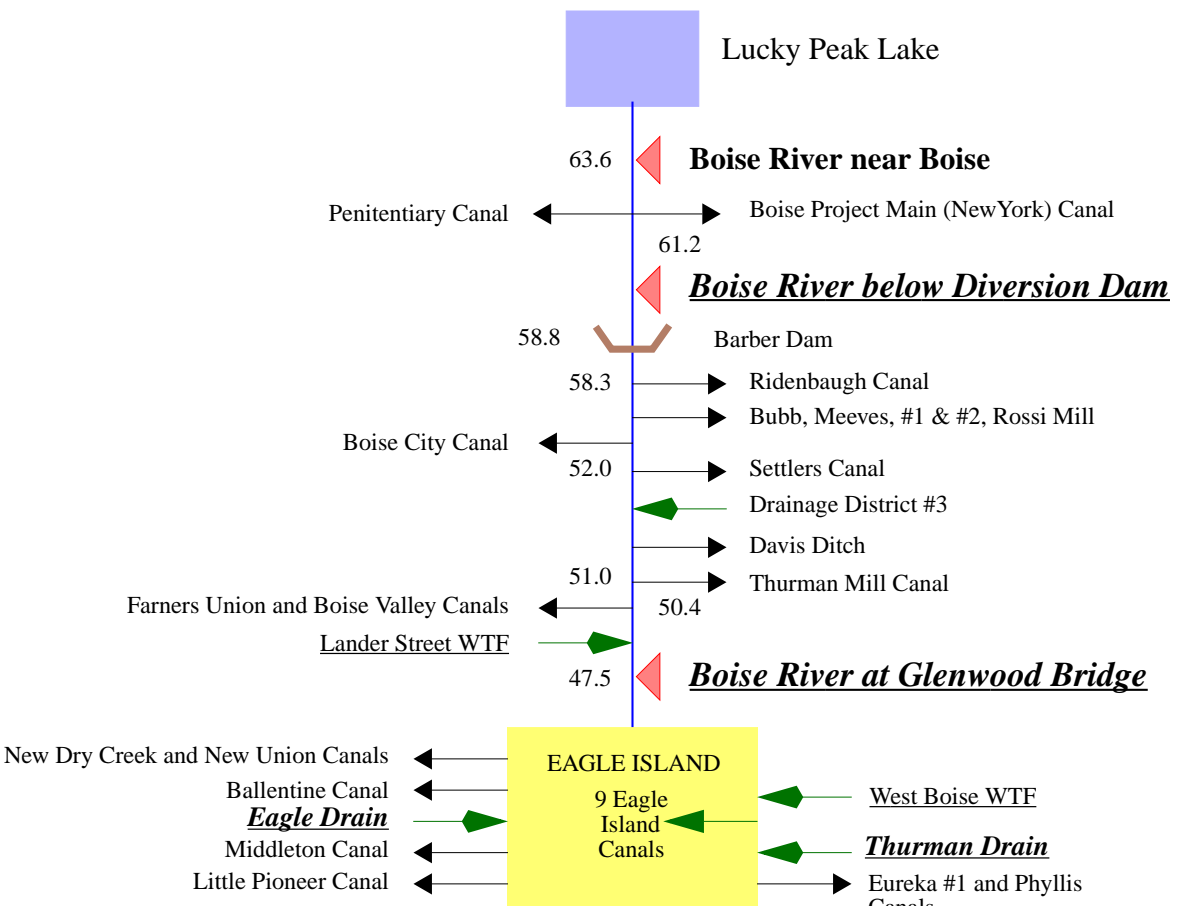

EAGLE ISLAND

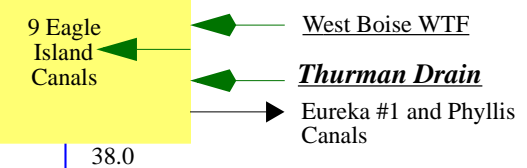

Canyon Canal

38.0

32.9

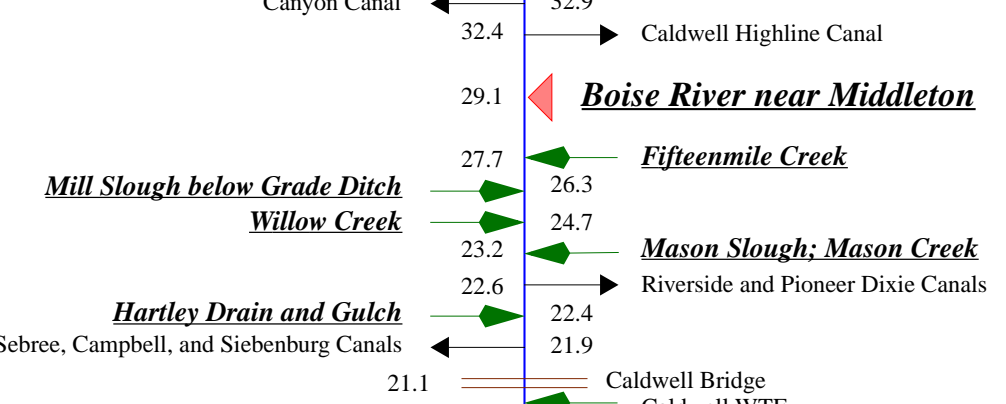

Sebree, Campbell, and Siebenburg Canals

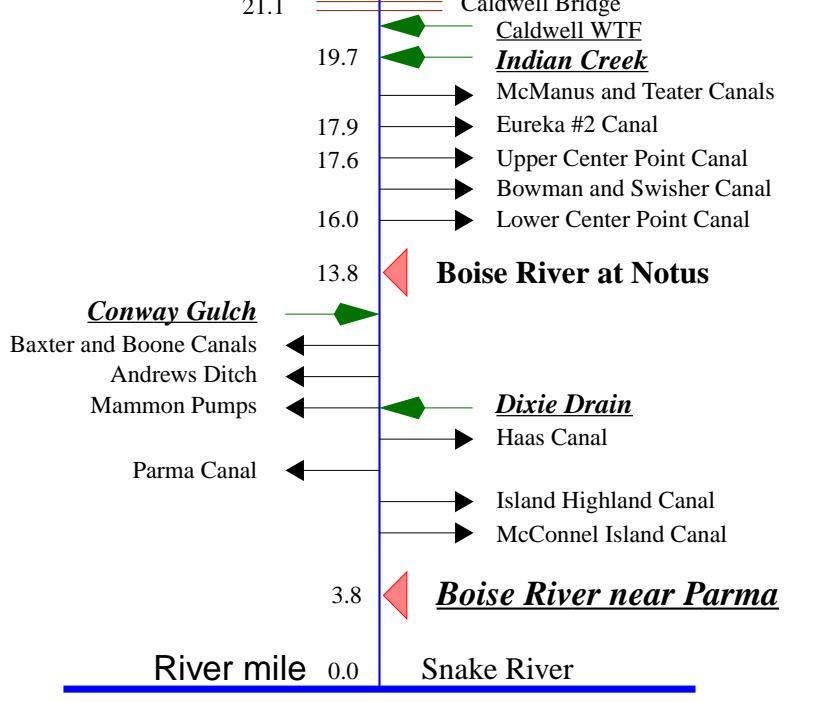

Figure 2. Schematic diagram of diversions, drains, and tributaries along the Boise River from Lucky Peak Lake to Snake River. (Modified from Warnick and Brockway, 1974; underlined sites are those sampled during this study) 


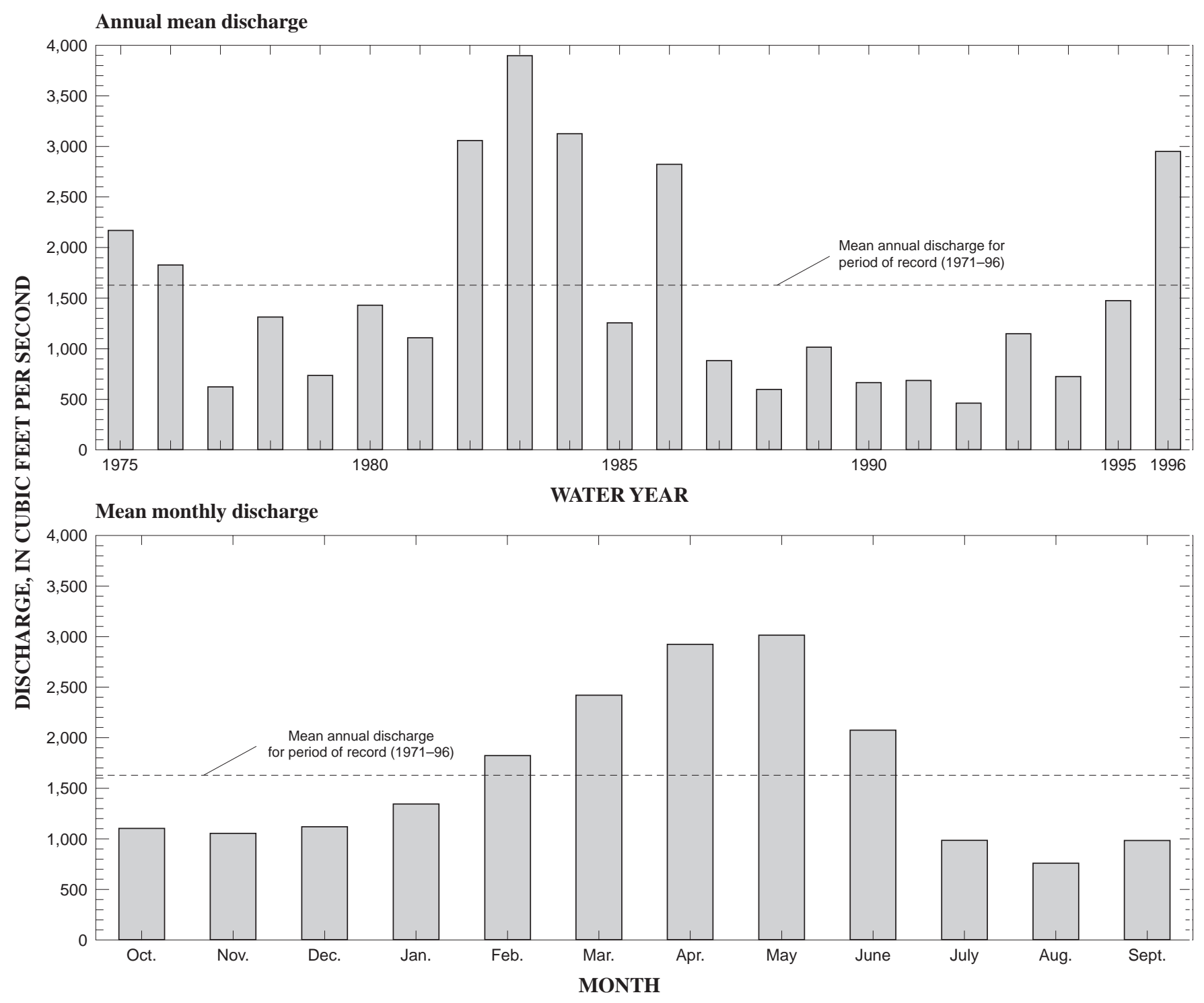

Figure 3. Annual mean discharge and mean monthly discharge in the Boise River near Parma, water years $1975-96$. (Site 21, figure 1)

\section{Ground Water}

Aquifers underlying the lower Boise River Basin are classified as deep or shallow. The widespread application of irrigation water, which began in 1863, has significantly altered the shallow ground-water system in the basin. Ground-water levels were reported to have risen as much as $140 \mathrm{ft}$ in some areas in the early 1900's (Nace and others, 1957, p. 10). Most of the recharge to the shallow aquifers results from the downward percolation of precipitation and irrigation water. Other sources of recharge include leakage from irrigation canals, lat- erals, and septic tank systems (Thomas and Dion, 1974, p. 13). The general direction of ground-water flow in the lower Boise River Basin is toward the river.

The shallow aquifer discharges fairly uniform flows to the Boise River, directly as seepage and indirectly through tributary streams and drains, primarily Fifteenmile Creek, Mason Creek, Indian Creek, and Dixie Drain (Thomas and Dion, 1974, p. 17). During most winters, nearly all the discharge to the Boise River be-tween Lucky Peak Lake and the mouth is from ground-water seepage. The post-irrigation season contribution of this 
ground-water seepage is about 300,000 acre-ft, roughly equivalent to the usable storage in Lucky Peak Lake or Arrowrock Reservoir (Thomas and Dion, 1974, p. 14).

\section{PREVIOUS INVESTIGATIONS}

Water quality was monitored in the lower Boise River and several of its tributaries during several past Federal and State monitoring programs. The most recent comprehensive monitoring of the lower Boise River and most of its major tributaries was in the early 1970's (Bureau of Reclamation, 1977). From July 1971 through October 1975, 1,616 water samples were collected from 56 sample locations as part of the monitoring study. Selected water-quality constituents, including nutrients, suspended sediment, and indicator bacteria from the Bureau of Reclamation study (1977) are summarized in table 1. The Bureau of Reclamation concluded that the Boise River entered the city of Boise with generally high-quality water. As the river passed through the city, water quality significantly deteriorated as a result of municipal and industrial wastewater discharges and stormwater runoff. Downstream to the mouth of the Boise River, the water quality further deteriorated, primarily from irrigation return flows and diversions, as well as from wastewater discharges from Meridian, Nampa, Caldwell, and individual industrial sites.

The Bureau of Reclamation study identified the primary constituents of concern in the Boise River as nutrients (nitrogen associated with irrigation return flows and phosphorus associated primarily with municipal discharges), fecal bacteria from municipal and agricultural sources, suspended solids in the river from irrigation return flows downstream from Star, and low dissolved oxygen in the lower reaches (Bureau of Reclamation, 1977). Water in tributary/drains in the basin varied widely in quality but generally declined in quality downstream. Factors contributing to degraded water quality in tributary/drains included shallow groundwater seepage, drain length and intensity of farming, quality of water applied to lands within the basin, and municipal and industrial effluents.

Several tributary/drains that discharge to the lower Boise River were monitored in the past. Of these, Conway Gulch was monitored for more than 20 years. Naylor and others (1976) reported that nitrate-nitrogen concentrations increased downstream in Conway Gulch and peaked in July. However, no trends were identified in nitrate-nitrogen concentrations in Wilson Drain, the only other drain sampled in that study, and the authors advised caution when attempting to extrapolate information from one drain to another.

In 1983, the IDEQ (formerly the Idaho Department of Health and Welfare, Division of Environment) reported the results of a water-quality monitoring program that was established for the irrigation drainage system in the lower Boise River Basin (Clark and Bauer, 1983). Two of the drains evaluated, Dixie Drain and Conway Gulch, empty into the Boise River and are part of the lower Boise River water-quality assessment. Among the conclusions drawn from the 1983 study were that all the evaluated drains transported large loads of nutrients (ni-trogen and phosphorus), sediment, fecal bacteria (primarily from livestock), and the organochlorine pesticides DDT and toxaphene.

During 1988-89, the IDEQ conducted additional monitoring of Conway Gulch to measure the effectiveness of Best Management Practices (BMPs) implemented in 1983 under the Conway Gulch Water Quality Project, a cooperative effort among the IDEQ, the Canyon Soil Conservation District, and cooperating landowners (Ingham, 1993). The goal of this project was to reduce point and nonpoint source agricultural effects on water quality through the implementation of BMPs. Monitoring results indicated that even with about 35 percent of the critical area under some form of treatment, Conway Gulch remained a major source of sediment, nutrients, trace elements, and bacteria to the lower Boise River. There were no significant changes in suspended or bedload sediment concentrations. Nutrient (nitrate and total phosphorus) concentrations exceeded criteria for the prevention of eutrophic conditions, and fecal bacteria concentrations continued to exceed State water-quality standards. Recommendations made in the IDEQ study included further reductions of erosion to reduce suspended sediment and total phosphorus loadings by in-corporating irrigation water management (a more conservative application of irrigation water) into existing treatments. Other potential BMPs identified included better fertilizer management, use of instream retention ponds (artificial wetlands), establishment of vegetation filter strips along Conway Gulch, and further evaluation of CAFOs and lands within the project area that directly affected Conway Gulch (Ingham, 1993, p. 27).

In 1989, the IDEQ reported that water quality in the lower Boise River steadily deteriorated from Lucky Peak Lake to the mouth as a result of frequent irrigation 
Table 1. Means and ranges for selected water-quality constituents reported by the Bureau of Reclamation in 1977 for sites in the lower Boise River Basin that correspond with sites measured by the U.S. Geological Survey from May 1994 through February 1997

[Mean values are listed on the top line for each site; ranges are listed in parentheses; values and ranges are from laboratory analyses unless identified as a field analysis; $\mu \mathrm{S} / \mathrm{cm}$; microsiemens per centimeter; $\mathrm{mg} / \mathrm{L}$, milligrams per liter; Dis., dissolved; col/100 mL, colonies per 100 milliliters; —, no data]

\begin{tabular}{|c|c|c|c|c|c|c|c|c|}
\hline Sampling site name & $\begin{array}{c}\text { Field pH } \\
\text { (standard units) }\end{array}$ & $\begin{array}{c}\text { Field specific } \\
\text { conductance } \\
(\mu \mathrm{S} / \mathrm{cm})\end{array}$ & $\begin{array}{c}\text { Dis. nitrite } \\
\text { plus nitrate } \\
(\mathrm{mg} / \mathrm{L})\end{array}$ & $\begin{array}{c}\text { Total } \\
\text { phosphorus } \\
\text { (mg/L) }\end{array}$ & $\begin{array}{c}\text { Dis. ortho- } \\
\text { phosphorus } \\
\text { (mg/L) }\end{array}$ & $\begin{array}{l}\text { Suspended } \\
\text { sediment } \\
(\mathrm{mg} / \mathrm{L})\end{array}$ & $\begin{array}{c}\text { Total } \\
\text { coliform } \\
\text { (col/100 mL) }\end{array}$ & $\begin{array}{c}\text { Fecal } \\
\text { coliform } \\
\text { (col/100 mL) }\end{array}$ \\
\hline Boise River below Lucky Peak Dam ${ }^{1} \ldots$. & $\begin{array}{c}27.2 \\
(6.57-7.61)\end{array}$ & $\begin{array}{c}77 \\
(50-100)\end{array}$ & $\begin{array}{c}0.15 \\
(0.06-2.6)\end{array}$ & $\begin{array}{c}0.04 \\
(0.02-0.16)\end{array}$ & $\begin{array}{c}0.01 \\
(0-0.04)\end{array}$ & $\begin{array}{c}20 \\
(4-108)\end{array}$ & $\begin{array}{c}151 \\
(0-1,030)\end{array}$ & $\begin{array}{c}1 \\
(0-10)\end{array}$ \\
\hline Boise River at Glenwood Bridge near Boise & $\begin{array}{c}27.48 \\
(7.06-7.92)\end{array}$ & $\begin{array}{c}106 \\
(63-174)\end{array}$ & $\begin{array}{c}0.23 \\
(0.1-0.54)\end{array}$ & $\begin{array}{c}0.22 \\
(0.04-0.86)\end{array}$ & $\begin{array}{c}0.16 \\
(0.01-0.78)\end{array}$ & $\begin{array}{c}15 \\
(2-64)\end{array}$ & $\begin{array}{c}4,787 \\
(28-40,000)\end{array}$ & $\begin{array}{c}886 \\
(0-16,000)\end{array}$ \\
\hline Eagle Drain at Eagle & $\begin{array}{c}27.55 \\
(7.20-7.96)\end{array}$ & $\begin{array}{c}281 \\
(220-360)\end{array}$ & $\begin{array}{c}1.03 \\
(0.47-1.75)\end{array}$ & $\begin{array}{c}0.18 \\
(0.09-0.26)\end{array}$ & $\begin{array}{c}0.12 \\
(0.05-0.17)\end{array}$ & $\begin{array}{c}23 \\
(4-74)\end{array}$ & $\begin{array}{c}4,106 \\
(600-22,000)\end{array}$ & $\begin{array}{c}570 \\
(0-1,940)\end{array}$ \\
\hline Thurman Drain near Eagle. . & $\begin{array}{c}27.89 \\
(7.57-8.38)\end{array}$ & $\begin{array}{c}493 \\
(380-600)\end{array}$ & $\begin{array}{c}2.27 \\
(1.12-3.47)\end{array}$ & $\begin{array}{c}0.15 \\
(0.09-0.20)\end{array}$ & $\begin{array}{c}0.11 \\
(0.07-0.14)\end{array}$ & $\begin{array}{c}297 \\
(180-368)\end{array}$ & $\begin{array}{c}2,203 \\
(80-22,200)\end{array}$ & $\begin{array}{c}153 \\
(0-1,200)\end{array}$ \\
\hline Boise River near Middleton. . & $\begin{array}{c}7.1 \\
(6.9-7.4)\end{array}$ & $\begin{array}{c}96 \\
(90-102)\end{array}$ & $\begin{array}{c}0.31 \\
(0.26-0.37)\end{array}$ & $\begin{array}{c}0.09 \\
(0.08-0.10)\end{array}$ & $\begin{array}{c}0.04 \\
(0.03-0.05)\end{array}$ & - & $\begin{array}{c}3,150 \\
(400-5,900)\end{array}$ & $\begin{array}{c}495 \\
(270-720)\end{array}$ \\
\hline Fifteenmile Creek at mouth near Middleton ${ }^{3} \ldots \ldots \ldots \ldots$ & $\begin{array}{c}7.7 \\
(7.0-8.6)\end{array}$ & $\begin{array}{c}429 \\
(185-705)\end{array}$ & $\begin{array}{c}1.86 \\
(0.71-3.28)\end{array}$ & $\begin{array}{c}0.39 \\
(0.13-0.81)\end{array}$ & $\begin{array}{c}0.27 \\
(0.09-0.45)\end{array}$ & $\begin{array}{c}64 \\
(2-208)\end{array}$ & $\begin{array}{c}10,914 \\
(1,000-46,000)\end{array}$ & $\begin{array}{c}1,829 \\
(0-18,800)\end{array}$ \\
\hline Mill Slough below Grade Ditch near Middleton ${ }^{4}$. & $\begin{array}{c}7.63 \\
(6.96-8.02)\end{array}$ & $\begin{array}{c}372 \\
(180-610)\end{array}$ & $\begin{array}{c}1.62 \\
(0.53-2.91)\end{array}$ & $\begin{array}{c}0.27 \\
(0.16-0.8)\end{array}$ & $\begin{array}{c}0.15 \\
(0.02-0.25)\end{array}$ & $\begin{array}{c}44 \\
(6-180)\end{array}$ & $\begin{array}{c}6,448 \\
(340-45,000)\end{array}$ & $\begin{array}{c}1,068 \\
(100-8,200)\end{array}$ \\
\hline Willow Creek at Highway 44 at Middleton. & $\begin{array}{c}7.5 \\
(7.4-7.7)\end{array}$ & $\begin{array}{c}265 \\
(100-730)\end{array}$ & $\begin{array}{c}0.85 \\
(0.15-2.42)\end{array}$ & $\begin{array}{c}0.41 \\
(0.20-0.84)\end{array}$ & $\begin{array}{c}0.22 \\
(0.05-0.3335)\end{array}$ & $\begin{array}{c}165 \\
(2-1,493)\end{array}$ & $\begin{array}{c}120 \\
(120-49,000)\end{array}$ & $\begin{array}{c}15 \\
(15-9,000)\end{array}$ \\
\hline Mason Slough at mouth near Caldwell ${ }^{5}$. & $\begin{array}{c}27.87 \\
(7.42-8.5)\end{array}$ & $\begin{array}{c}536 \\
(360-740\end{array}$ & $\begin{array}{c}1.21 \\
(0.53-2.12)\end{array}$ & $\begin{array}{c}0.35 \\
(0.10-1.21)\end{array}$ & $\begin{array}{c}0.26 \\
(0.05-1.00)\end{array}$ & $\begin{array}{c}33 \\
(2-128)\end{array}$ & $\begin{array}{c}7,403 \\
(100-50,000)\end{array}$ & $\begin{array}{c}1,142 \\
(2-18,400)\end{array}$ \\
\hline Mason Creek at mouth near Caldwell ${ }^{6} \ldots \ldots \ldots \ldots \ldots$ & $\begin{array}{c}8.2 \\
(8.1-8.4)\end{array}$ & $\begin{array}{c}567 \\
(240-860)\end{array}$ & $\begin{array}{c}2.92 \\
(1.47-4.83)\end{array}$ & $\begin{array}{c}0.41 \\
(0.14-1.67)\end{array}$ & $\begin{array}{c}0.22 \\
(0.08-0.99)\end{array}$ & $\begin{array}{c}82 \\
(8-264)\end{array}$ & $\begin{array}{c}14,818 \\
(400-123,000)\end{array}$ & $\begin{array}{c}3,181 \\
(30-75,200)\end{array}$ \\
\hline West Hartley Drain (Gulch) near Caldwell . & $\begin{array}{c}7.5 \\
(6.8-8.1)\end{array}$ & $\begin{array}{c}454 \\
(220-710)\end{array}$ & $\begin{array}{c}1.95 \\
(0.49-4.13)\end{array}$ & $\begin{array}{c}0.49 \\
(0.09-1.3)\end{array}$ & $\begin{array}{c}0.35 \\
(0.04-0.7)\end{array}$ & $\begin{array}{c}55 \\
(6-160)\end{array}$ & $\begin{array}{c}14,958 \\
(200-62,000)\end{array}$ & $\begin{array}{c}2,968 \\
(0-24,000)\end{array}$ \\
\hline East Hartley Drain (Gulch) near Caldwell. & $\begin{array}{c}27.87 \\
(7.24-8.78)\end{array}$ & $\begin{array}{c}668 \\
(345-1,000)\end{array}$ & $\begin{array}{c}2.01 \\
(0.89-3.51)\end{array}$ & $\begin{array}{c}0.38 \\
(0.26-0.75)\end{array}$ & $\begin{array}{c}0.24 \\
(0.16-0.36)\end{array}$ & $\begin{array}{c}82 \\
(15-268)\end{array}$ & $\begin{array}{c}15,978 \\
(1,600-100,000)\end{array}$ & $\begin{array}{c}5,148 \\
(0-48,400)\end{array}$ \\
\hline Indian Creek at mouth near Caldwell & $\begin{array}{c}7.8 \\
(7.2-8.2)\end{array}$ & $\begin{array}{c}600 \\
(240-840)\end{array}$ & $\begin{array}{c}2.42 \\
(0.73-3.93)\end{array}$ & $\begin{array}{c}0.42 \\
(0.25-0.75)\end{array}$ & $\begin{array}{c}0.28 \\
(0.08-0.50)\end{array}$ & $\begin{array}{c}66 \\
(4-338)\end{array}$ & $\begin{array}{c}30,328 \\
(300-730,000)\end{array}$ & $\begin{array}{c}2,921 \\
(50-60,000)\end{array}$ \\
\hline Conway Gulch at Notus $\ldots \ldots \ldots \ldots \ldots \ldots \ldots \ldots$ & $\begin{array}{c}27.9 \\
(7.5-8.3)\end{array}$ & $\begin{array}{c}787 \\
(395-1,145)\end{array}$ & $\begin{array}{c}2.86 \\
(1.62-4.05)\end{array}$ & $\begin{array}{c}0.49 \\
(0.17-2.42)\end{array}$ & $\begin{array}{c}0.22 \\
(0.15-1.1)\end{array}$ & $\begin{array}{c}173 \\
(6-926)\end{array}$ & $\begin{array}{c}12,318 \\
(100-164,000)\end{array}$ & $\begin{array}{c}740 \\
(10-3,300)\end{array}$ \\
\hline Dixie Drain near Wilder. . & $\begin{array}{c}8.2 \\
(8.0-8.4)\end{array}$ & $\begin{array}{c}649 \\
(330-900)\end{array}$ & $\begin{array}{c}1.90 \\
(0.75-3.55)\end{array}$ & $\begin{array}{c}0.43 \\
0.17-1.46)\end{array}$ & $\begin{array}{c}0.23 \\
(0.08-0.65)\end{array}$ & $\begin{array}{c}70 \\
(13-214)\end{array}$ & $\begin{array}{c}134,224 \\
(1,000-1,200,000)\end{array}$ & $\begin{array}{c}4,180 \\
(50-70,000)\end{array}$ \\
\hline
\end{tabular}

${ }^{1}$ Closest upstream site to Boise River below Diversion Dam.

${ }^{2} \mathrm{Lab} \mathrm{pH}$ values; no or insufficient field $\mathrm{pH}$ values were reported.

${ }_{3}^{3}$ Identified as Tenmile Creek in Bureau of Reclamation report (1977).

4 Combined North and South Midleton Drain in Bureau of Reclanation report (1977).

Combined Mason Creek North Channel and Mason Creek South Channel in Bureau of Reclamation report (1977).

${ }^{6}$ Mason Drain in Bureau of Reclamation report (1977). 
withdrawals and returns, as well as municipal wastewater discharges. Water quality near Parma was classified as poor, due to "excessive bacteria, nutrients, sediment, and metals, as well as elevated temperatures" (Idaho Department of Health and Welfare, 1989, p. 46).

Water from five major storm-sewer outfalls that empty into the Boise River in Boise and Garden City was sampled by the USGS during 1993-94 (Kjelstrom, 1995) to assess the suitability of regional and adjusted regional models to estimate runoff volume and loads from storm-sewer outfalls. Samples were analyzed for nutrients, dissolved and suspended solids, trace elements, organic compounds, major ions, specific conductance, $\mathrm{pH}$, alkalinity, water temperature, oxygen demand, and indicator bacteria. Mean annual runoff volumes and loads were estimated by computing runoff volume and loads for 904 storms during 1976 through 1993.

The City of Boise recently reported that storm runoff within Boise contributes relatively minor pollutant loads to the Boise River for four reasons: (1) About 61 percent of the urban runoff from Boise is diverted

Table 2. Water-quality constituents analyzed in samples from sites in the lower Boise River Basin, May 1994 through February 1997

[WATSTORE, WATer data STOrage and REtrieval system; - , not applica$\mathrm{ble} ; \mathrm{ft}^{3} / \mathrm{s}$, cubic feet per second; $\mathrm{mg} / \mathrm{L}$, milligrams per liter; $\mu \mathrm{S} / \mathrm{cm}$, microsiemens per centimeter; dis., dissolved; N, nitrogen; tot., total; P, phosphorus; ortho, orthophosphorus; $\mathrm{mL}$, milliliter]

\begin{tabular}{|c|c|c|}
\hline Constituent & $\begin{array}{l}\text { WATSTORE } \\
\text { parameter } \\
\text { code }\end{array}$ & $\begin{array}{c}\text { Reporting } \\
\text { level }\end{array}$ \\
\hline \multicolumn{3}{|l|}{ Field analyses } \\
\hline Instantaneous discharge $\left(\mathrm{ft}^{3} / \mathrm{s}\right) \ldots$ & 00061 & - \\
\hline Alkalinity $\left(\mathrm{mg} / \mathrm{L}\right.$ as $\left.\mathrm{CaCO}_{3}\right) \ldots$ & 00418 & - \\
\hline Dissolved oxygen $(\mathrm{mg} / \mathrm{L}) \ldots \ldots \ldots \ldots$ & 00300 & - \\
\hline Dissolved oxygen saturation (percent). . & 00301 & - \\
\hline $\mathrm{pH}$ (standard units). . . . . . . . . . . & 00400 & - \\
\hline Specific conductance $(\mu \mathrm{S} / \mathrm{cm}) \ldots \ldots$ & 00095 & - \\
\hline Water temperature (degrees Celsius). & 00010 & - \\
\hline Air temperature (degrees Celsius) .... & 00200 & - \\
\hline \multicolumn{3}{|l|}{ Nutrients } \\
\hline Nitrogen, dis., ammonia (mg/L as N) & 00608 & 0.015 \\
\hline Nitrogen, dis., ammonia + organic $(\mathrm{mg} / \mathrm{L}$ as $\mathrm{N})$ & 00623 & .2 \\
\hline Nitrogen, tot., ammonia + organic $(\mathrm{mg} / \mathrm{L}$ as $\mathrm{N})$. & 00625 & .2 \\
\hline Nitrogen, dis., nitrite + nitrate $(\mathrm{mg} / \mathrm{L}$ as $\mathrm{N}) \ldots \ldots$ & 00631 & .1 \\
\hline Phosphorus, tot. $(\mathrm{mg} / \mathrm{L}$ as $\mathrm{P}) \ldots \ldots \ldots \ldots \ldots \ldots \ldots$. & 00665 & .01 \\
\hline Phosphorus, dis. $(\mathrm{mg} / \mathrm{L}$ as $\mathrm{P}) \ldots \ldots \ldots \ldots \ldots$ & 00666 & .01 \\
\hline Phosphorus, dis., ortho $(\mathrm{mg} / \mathrm{L}$ as $\mathrm{P}) \ldots .$. & 00671 & .01 \\
\hline \multicolumn{3}{|l|}{ Sediment } \\
\hline Suspended sediment $(\mathrm{mg} / \mathrm{L}) \ldots \ldots \ldots \ldots \ldots \ldots \ldots$ & 80154 & - \\
\hline \multicolumn{3}{|l|}{ Bacteria } \\
\hline Total coliform (colonies $/ 100 \mathrm{~mL}$ ) . . & 31501 & - \\
\hline Fecal coliform (colonies $/ 100 \mathrm{~mL}$ ) ... & 31625 & - \\
\hline
\end{tabular}

into other waterways before entering the Boise River and is reused as irrigation water, (2) about 10 percent of the urban impact area retains stormwater onsite, (3) only 42 percent of the average annual precipitation creates runoff because of small storm size and evaporation, and (4) Boise is not heavily industrialized and supports primarily clean industries (Joan Meitl, Boise City Stormwater Coordinator, written commun., 1998).

\section{METHODS OF DATA COLLECTION AND ANALYSIS}

Water-quality analyses included field analyses (alkalinity, dissolved oxygen, $\mathrm{pH}$, specific conductance, and water temperature), nutrients (nitrogen and phosphorus), suspended sediment, and total and fecal coliform bacteria (table 2). Sampling site locations are listed in table 3.

Depth- and width-integrated water samples were collected and processed according to the methods described by Edwards and Glysson (1988) and Shelton (1994). Water samples were composited in a churn splitter from which subsamples were obtained. Unfiltered water in the churn was mixed thoroughly to accurately represent water collected in each cross section. Water samples to be analyzed for dissolved constituents were filtered through a $0.45-\mu \mathrm{m}$-pore-size capsule filter. Samples were preserved at $4^{\circ} \mathrm{C}$ until analysis. Nutrients were analyzed by the USGS National Water-Quality Laboratory according to methods described by Fishman (1993) and quality-assurance/quality-control protocols as described by Pritt and Raese (1995). Approximately 10 percent of the nutrient samples were submitted as duplicates or blanks for quality-assurance purposes as described by Friedman and Erdmann (1982).

Suspended sediment was analyzed by the USGS Cascades Volcano Observatory Sediment Laboratory according to methods described by Guy (1969).

Alkalinity, $\mathrm{pH}$, and specific conductance were measured in depth- and width-integrated samples by using electrometric meters that were calibrated at the beginning of each sampling day. Alkalinity, bicarbonate, and carbonate were measured using the fixed end-point method (Shelton, 1994).

Dissolved oxygen and water temperature were measured at the stream centroid by using an electrometric meter. The dissolved oxygen meter was calibrated at the beginning of each sampling day and frequently recalibrated during the day. Ambient air temperature also was 
Table 3. Locations of sampling sites, types of samples collected, and collection frequency, lower Boise River Basin, May 1994 through February 1997

[Sampling site locations are shown by reference number on figure 1. Sampling site name abbreviation prefix: R, river; W, wastewater treatment facility; N, northside tributary/drain; S, southside tributary/drain. Sample collection frequency: S, synoptic; I, interval; B, biological site sampled once annually]

\begin{tabular}{|c|c|c|c|c|c|c|c|c|c|}
\hline \multirow{2}{*}{$\begin{array}{l}\text { Sampling } \\
\text { site } \\
\text { reference } \\
\text { number } \\
\text { (figure 1) }\end{array}$} & \multirow[b]{2}{*}{$\begin{array}{l}\text { U.S. Geological Survey } \\
\text { sampling site name and number }\end{array}$} & \multirow{2}{*}{$\begin{array}{l}\text { Sampling } \\
\text { site name } \\
\text { abbreviation }\end{array}$} & \multirow[b]{2}{*}{ Latitude } & \multirow[b]{2}{*}{ Longitude } & \multicolumn{2}{|c|}{ Sample type } & \multicolumn{3}{|c|}{ Sample collection frequency } \\
\hline & & & & & $\begin{array}{l}\text { Water } \\
\text { quality }\end{array}$ & Biological & $\frac{\text { Sam }}{\mathrm{S}}$ & ecti & $\frac{\text { uency }}{\text { B }}$ \\
\hline 1 & $\begin{array}{l}\text { Boise River below Diversion Dam } \\
\quad \text { near Boise }(13203510) \ldots \ldots \ldots \ldots \ldots \ldots \ldots\end{array}$ & R-DIV & $43^{\circ} 32^{\prime} 23^{\prime \prime}$ & $116^{\circ} 05^{\prime} 37^{\prime \prime}$ & $\mathrm{x}$ & & $\mathrm{x}$ & $\mathrm{x}$ & \\
\hline 2 & Boise River at Eckert Road near Boise (13203760) . . . . . . & R-ECK & $43^{\circ} 33^{\prime} 57^{\prime \prime}$ & $116^{\circ} 07^{\prime} 52^{\prime \prime}$ & & $\mathrm{x}$ & & & $\mathrm{x}$ \\
\hline 3 & Lander Street Wastewater Treatment Facility ........... & W-LAN & $43^{\circ} 38^{\prime} 26^{\prime \prime}$ & $116^{\circ} 15^{\prime} 32^{\prime \prime}$ & $\mathrm{x}$ & & $\mathrm{x}$ & $\mathrm{x}$ & \\
\hline 4 & $\begin{array}{l}\text { Boise River at Glenwood Bridge } \\
\quad \text { near Boise }(13206000) \ldots \ldots \ldots \ldots \ldots \ldots \ldots\end{array}$ & R-GLN & $43^{\circ} 39^{\prime} 37^{\prime \prime}$ & $116^{\circ} 16^{\prime} 41^{\prime \prime}$ & $\mathrm{x}$ & $\mathrm{x}$ & $\mathrm{x}$ & $\mathrm{x}$ & $\mathrm{x}$ \\
\hline 5 & West Boise Wastewater Treatment Facility . . . . . . . . . & W-WST & $43^{\circ} 40^{\prime} 03^{\prime \prime}$ & $116^{\circ} 10^{\prime} 20^{\prime \prime}$ & $\mathrm{x}$ & & $\mathrm{x}$ & $\mathrm{x}$ & \\
\hline 6 & Eagle Drain at Eagle $(13206400) \quad \ldots \ldots$. . . & N-EAG & $43^{\circ} 41^{\prime} 38^{\prime \prime}$ & $116^{\circ} 21^{\prime} 11^{\prime \prime}$ & $\mathrm{x}$ & & $\mathrm{x}$ & & \\
\hline 7 & Thurman Drain near Eagle $(13208750) \ldots \ldots \ldots \ldots \ldots$ & S-THR & $43^{\circ} 40^{\prime} 18^{\prime \prime}$ & $116^{\circ} 22^{\prime} 29^{\prime \prime}$ & $\mathrm{x}$ & & $\mathrm{x}$ & & \\
\hline 8 & Boise River near Middleton $(13210050) \ldots \ldots \ldots \ldots \ldots$. . . . & R-MID & $43^{\circ} 41^{\prime} 06^{\prime \prime}$ & $116^{\circ} 34^{\prime} 22^{\prime \prime}$ & $\mathrm{x}$ & $\mathrm{x}$ & $\mathrm{x}$ & $\mathrm{x}$ & $\mathrm{x}$ \\
\hline 9 & $\begin{array}{l}\text { Fifteenmile Creek at mouth } \\
\quad \text { near Middleton }(13210815) \ldots \ldots \ldots \ldots \ldots \ldots \ldots\end{array}$ & S-FIF & $43^{\circ} 41^{\prime} 16^{\prime \prime}$ & $116^{\circ} 35^{\prime} 25^{\prime \prime}$ & $\mathrm{x}$ & & $\mathrm{x}$ & $\mathrm{x}$ & \\
\hline 10 & $\begin{array}{l}\text { Mill Slough below Grade Ditch } \\
\text { near Middleton (132108247) . }\end{array}$ & N-MIL & $43^{\circ} 42^{\prime} 04^{\prime \prime}$ & $116^{\circ} 37^{\prime} 02^{\prime \prime}$ & $\mathrm{x}$ & & $\mathrm{x}$ & & \\
\hline 11 & $\begin{array}{l}\text { Willow Creek at Highway } 44 \\
\quad \text { at Middleton }(13210835) \ldots \ldots \ldots \ldots \ldots \ldots \ldots\end{array}$ & N-WIL & $43^{\circ} 42^{\prime} 24^{\prime \prime}$ & $116^{\circ} 37^{\prime} 47^{\prime \prime}$ & $\mathrm{x}$ & & $\mathrm{x}$ & $\mathrm{x}$ & \\
\hline 12 & Mason Slough at mouth near Caldwell $(13210850) \ldots \ldots$. & S-MSS & $43^{\circ} 41^{\prime} 32^{\prime \prime}$ & $116^{\circ} 39^{\prime} 56^{\prime \prime}$ & $\mathrm{x}$ & & $\mathrm{x}$ & & \\
\hline 13 & Mason Creek at mouth near Caldwell (13210985) . . . . . . . . & S-MSC & $43^{\circ} 41^{\prime} 55^{\prime \prime}$ & $116^{\circ} 40^{\prime} 22^{\prime \prime}$ & $\mathrm{x}$ & & $\mathrm{x}$ & $\mathrm{x}$ & \\
\hline 14 & $\begin{array}{l}\text { West Hartley Drain (Gulch) } \\
\quad \text { near Caldwell }(13210986) \ldots \ldots \ldots \ldots \ldots\end{array}$ & N-WHR & $43^{\circ} 41^{\prime} 59^{\prime \prime}$ & $116^{\circ} 41^{\prime} 95^{\prime \prime}$ & $\mathrm{x}$ & & $\mathrm{x}$ & $\mathrm{x}$ & \\
\hline 15 & $\begin{array}{l}\text { East Hartley Drain (Gulch) } \\
\quad \text { near Caldwell }(13210987) \ldots \ldots \ldots \ldots \ldots \ldots \ldots\end{array}$ & N-EHR & $43^{\circ} 41^{\prime} 56^{\prime \prime}$ & $116^{\circ} 40^{\prime} 38^{\prime \prime}$ & $\mathrm{x}$ & & $\mathrm{x}$ & $\mathrm{x}$ & \\
\hline 16 & $\begin{array}{l}\text { Boise River at Highway } 20-26 \text { crossing } \\
\quad \text { near Caldwell }(13211000) \ldots \ldots \ldots \ldots \ldots \ldots \ldots\end{array}$ & R-CLD & $43^{\circ} 40^{\prime} 52^{\prime \prime}$ & $116^{\circ} 41^{\prime} 18^{\prime \prime}$ & & $\mathrm{x}$ & & & $\mathrm{x}$ \\
\hline 17 & Caldwell Wastewater Treatment Facility . . . . . . . . . . & W-CLD & $43^{\circ} 40^{\prime} 27^{\prime \prime}$ & $116^{\circ} 41^{\prime} 52^{\prime \prime}$ & $\mathrm{x}$ & & $\mathrm{x}$ & $\mathrm{x}$ & \\
\hline 18 & Indian Creek at mouth at Caldwell (13211445) ......... & S-IND & $43^{\circ} 41^{\prime} 26^{\prime \prime}$ & $116^{\circ} 42^{\prime} 05^{\prime \prime}$ & $\mathrm{x}$ & & $\mathrm{x}$ & $\mathrm{x}$ & \\
\hline 19 & $\begin{array}{l}\text { Conway Gulch at Highway } 20-26 \text { crossing } \\
\text { at Notus }(13212550) \ldots \ldots \ldots \ldots \ldots \ldots\end{array}$ & $\mathrm{N}-\mathrm{CON}$ & $43^{\circ} 43^{\prime} 36^{\prime \prime}$ & $116^{\circ} 48^{\prime} 12^{\prime \prime}$ & $\mathrm{x}$ & & $\mathrm{x}$ & $\mathrm{x}$ & \\
\hline 20 & Dixie Drain near Wilder $(13212890) \ldots \ldots \ldots \ldots \ldots \ldots$ & S-DIX & $43^{\circ} 43^{\prime} 51^{\prime \prime}$ & $116^{\circ} 53^{\prime} 17^{\prime \prime}$ & $\mathrm{x}$ & & $\mathrm{x}$ & $\mathrm{x}$ & \\
\hline 21 & Boise River near Parma $(13213000 \ldots \ldots \ldots \ldots \ldots \ldots$. . . . . . . & R-PAR & $43^{\circ} 46^{\prime} 54^{\prime \prime}$ & $116^{\circ} 58^{\prime} 17^{\prime \prime}$ & $\mathrm{x}$ & & $\mathrm{x}$ & $\mathrm{x}$ & \\
\hline 22 & Boise River at mouth near Parma (13213030) $\ldots \ldots \ldots \ldots$ & R-MTH & $43^{\circ} 48^{\prime} 50^{\prime \prime}$ & $117^{\circ} 00^{\prime} 55^{\prime \prime}$ & & $\mathrm{x}$ & & & $\mathrm{x}$ \\
\hline
\end{tabular}


measured at each sampling site by using thermometers calibrated to within $0.5^{\circ} \mathrm{C}$ against National Institute of Standards and Technology standard thermometers. Additional water temperature data were collected hourly during the summer of 1996 using Hobo continuous temperature recorders (Onset Computer Corporation). Recorders were deployed at five main-stem Boise River sites (sites 1, 4, 8, 16, and 22; table 3) from July 18 through September 5.

Total and fecal coliform bacteria concentrations were measured using membrane-filter methods (Britton and Greeson, 1987). Water samples for bacterial analysis were collected at the stream centroid.
For sites not equipped with continuous stage recorders, instantaneous stream discharge was measured using methods described by Buchanan and Somers (1969).

Instantaneous loads of total nitrogen, total phosphorus, and suspended sediment were calculated for agricultural drain and river sites by multiplying the discharge measured at the time of sampling by the associated concentration.

Discharge plotted on flow-duration curves for the four sites on the lower Boise River indicates that waterquality samples were collected over a range of mediumlow to high flows (fig. 4).
Sampling site 1 Boise River below Diversion Dam near Boise

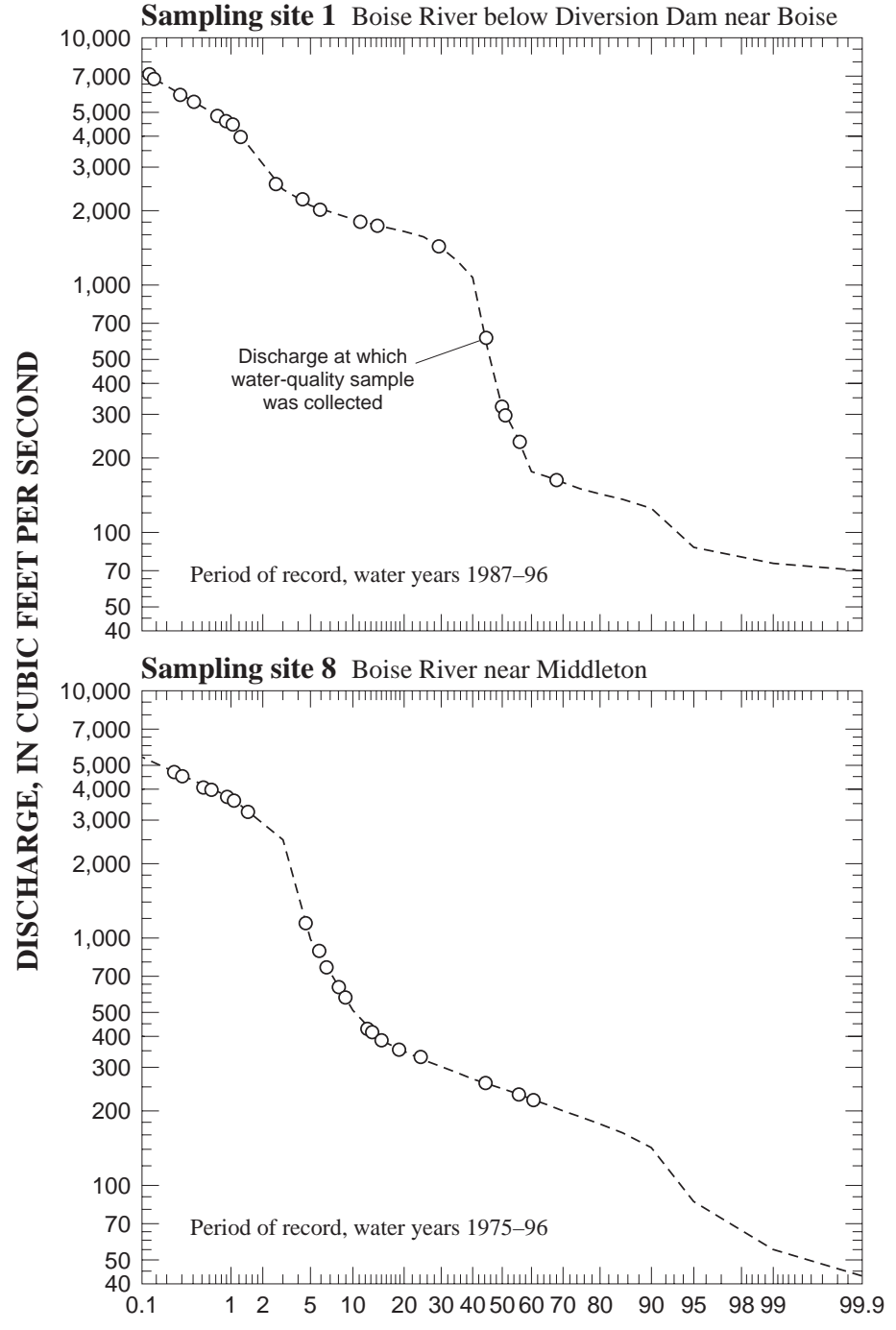

Sampling site 4 Boise River at Glenwood Bridge near Boise

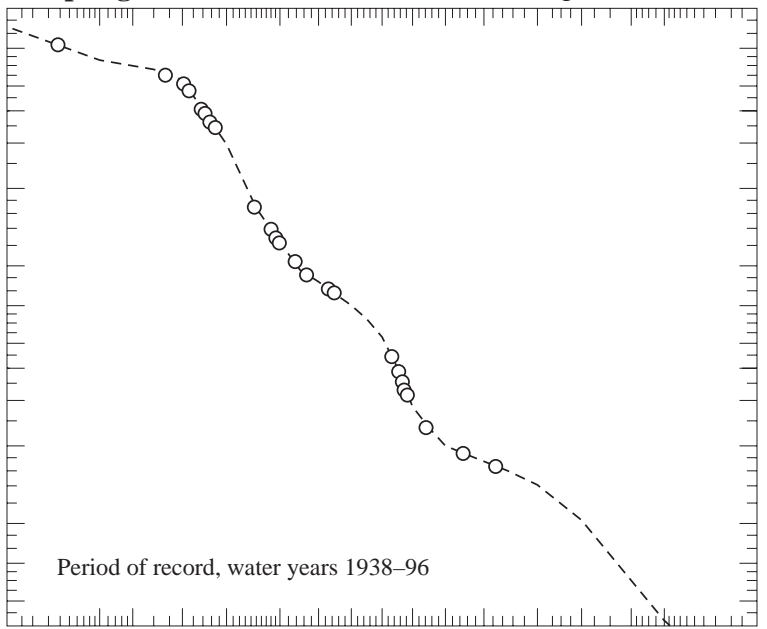

Sampling site 21 Boise River near Parma

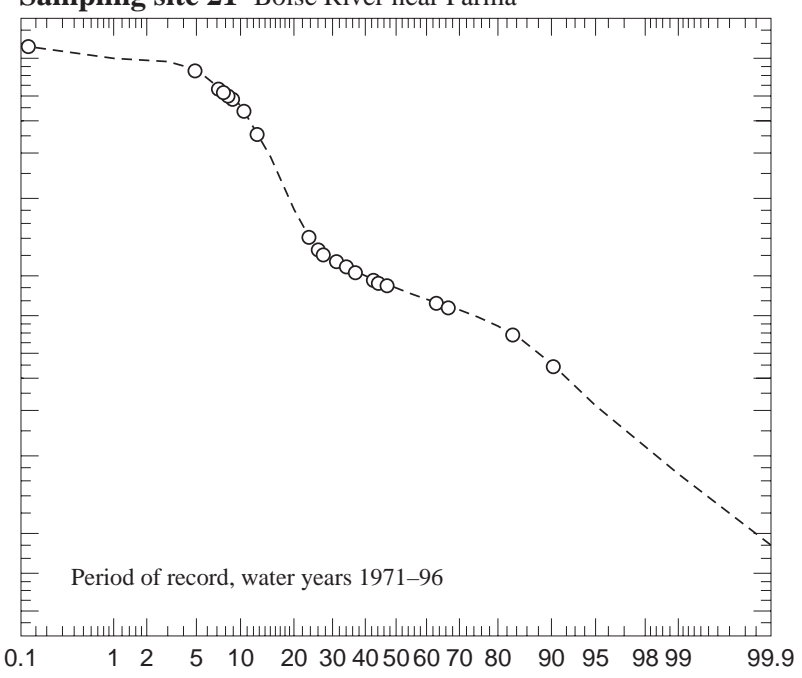

PERCENT OF TIME DISCHARGE WAS EQUALED OR EXCEEDED

Figure 4. Discharges at which water-quality samples were collected at Boise River sites, May 1994 through February 1997. (Dashed lines represent the discharge-duration curve over the period of record for the indicated site) 


\section{WATER-QUALITY CONDITIONS}

\section{Nitrogen}

Nitrogen is essential to the metabolism of aquatic plants. The supply-to-demand ratio for nitrogen is small; thus, nitrogen can limit the growth of aquatic plants as phosphorus often does. The nitrogen cycle in aquatic ecosystems is complex because most processes involving nitrogen are biologically mediated. In aquatic ecosystems, nitrogen commonly exists in the following forms: dissolved molecular nitrogen, nitrogen-containing organic compounds, ammonia, ammonium, nitrite, and nitrate. Analyses for this study included dissolved ammonia (includes ammonium), dissolved and total ammonia plus organic nitrogen (commonly called kjel-

Table 4. Statistical summary of total nitrogen concentrations and instantaneous loads in samples from sites in the lower Boise River Basin, May 1994 through February 1997

[Sampling site locations are shown by reference number in figure 1 and are listed in table 3; N, nitrogen; WTF, wastewater treatment facility]

\begin{tabular}{|c|c|c|c|c|c|}
\hline $\begin{array}{l}\text { Sampling } \\
\text { site } \\
\text { reference }\end{array}$ & & $\begin{array}{c}\text { Number } \\
\text { of }\end{array}$ & $\begin{array}{r}\text { Conce } \\
\text { load }\end{array}$ & $\begin{array}{l}\text { or i } \\
\text { atec }\end{array}$ & $\begin{array}{c}\text { Maximum } \\
\text { concentration or } \\
\text { instantaneous }\end{array}$ \\
\hline number & Site name & samples & 25 & 50 & load \\
\hline
\end{tabular}

Total nitrogen, milligrams per liter as $\mathbf{N}$

\begin{tabular}{|c|c|}
\hline 1 & Boise River below Diversion Dam . . . . \\
\hline 3 & Lander Street WTF . . . . . . . . . . . . . \\
\hline 4 & Boise River at Glenwood Bridge. . . . . . \\
\hline 5 & West Boise WTF . . . . . . . . . . . . \\
\hline 6 & Eagle Drain at Eagle . . . . . . . \\
\hline 7 & Thurman Drain near Eagle . \\
\hline 8 & Boise River near Middleton. . . . . . . . . . \\
\hline 9 & Fifteenmile Creek at mouth. . . . . . . . . \\
\hline & Mill Slough below Grade Ditch . . . . . . \\
\hline & Willow Creek at Middleton . . . . . . . . . . \\
\hline & Mason Slough at mouth. . . . . . . . . . . \\
\hline & Mason Creek at mouth $\ldots \ldots \ldots \ldots$ \\
\hline & West Hartley Gulch near Caldwell . . . . \\
\hline & East Hartley Gulch near Caldwell. . . . . \\
\hline & Caldwell WTF . . . . . . . . . . . . . \\
\hline & Indian Creek at mouth. . \\
\hline & Conway Gulch at Notus . . . . \\
\hline & Dixie Drain at mouth. . . \\
\hline & Boise River near Parma. . \\
\hline
\end{tabular}

$\begin{array}{rrr}20 & 0.2 & 0.2 \\ 18 & 13.8 & 14.9 \\ 25 & .3 & .4 \\ 18 & 14.1 & 19.2 \\ 5 & 1.5 & 1.9 \\ 5 & 2.0 & 2.3 \\ 20 & .5 & .7 \\ 18 & 1.8 & 3.2 \\ 5 & 2.1 & 2.7 \\ 18 & .8 & 1.1 \\ 5 & 2.2 & 3.7 \\ 18 & 3.75 & 4.7 \\ 18 & 1.6 & 2.8 \\ 18 & 3.0 & 3.9 \\ 17 & 9.1 & 11.1 \\ 18 & 3.1 & 4.2 \\ 18 & 3.7 & 4.9 \\ 18 & 2.3 & 2.9 \\ 21 & 1.2 & 2.0\end{array}$

Total nitrogen, instantaneous load, pounds per day as $\mathbf{N}$

\begin{tabular}{|c|c|c|c|c|c|}
\hline Boise River below Diversion Dam .... & 20 & 377 & 2,320 & 7,500 & 19,800 \\
\hline Lander Street WTF . . . . . . . . . . . & 18 & 1,100 & 1,170 & 1,400 & 1,660 \\
\hline Boise River at Glenwood Bridge. . . . . . & 25 & 1,300 & 1,840 & 6,470 & 16,200 \\
\hline West Boise WTF . . . . . . . . . . . . & 18 & 1,690 & 2,230 & 2,850 & 3,470 \\
\hline Eagle Drain at Eagle . . . . . . . . . & 5 & 161 & 250 & 306 & 315 \\
\hline Thurman Drain near Eagle . . . . . . . . . & 5 & 151 & 221 & 323 & 360 \\
\hline Boise River near Middleton. . . . . . . . . . & 20 & 2,470 & 4,080 & 7,630 & 14,900 \\
\hline Fifteenmile Creek at mouth. . . . . . . . & 18 & 995 & 1,480 & 1,730 & 2,900 \\
\hline Mill Slough below Grade Ditch . . . . . . & 5 & 1,480 & 1,600 & 1,700 & 1,730 \\
\hline Willow Creek at Middleton . . . . . . . . . & 18 & 153 & 238 & 382 & 522 \\
\hline Mason Slough at mouth. . . . . . . . . . & 5 & 204 & 261 & 555 & 838 \\
\hline Mason Creek at mouth $\ldots \ldots \ldots \ldots$ & 18 & 1,580 & 2,260 & 2,770 & 3,520 \\
\hline West Hartley Gulch near Caldwell . . . . & 18 & 173 & 229 & 276 & 522 \\
\hline East Hartley Gulch near Caldwell. . . . . & 18 & 566 & 789 & 1,020 & 1,590 \\
\hline Caldwell WTF. . . . . . . . . . . . . & 17 & 366 & 431 & 480 & 563 \\
\hline Indian Creek at mouth . . . . . . . . . & 18 & 1,560 & 2,310 & 7,730 & 9,110 \\
\hline Conway Gulch at Notus . . . . . . . . . & 18 & 646 & 840 & 952 & 1,120 \\
\hline Dixie Drain at mouth . . . . . . . . . & 18 & 2,260 & 2,570 & 3,550 & 5,390 \\
\hline Boise River near Parma . . . . . . . . . . & 21 & 13,400 & 20,800 & 26,500 & 53,500 \\
\hline
\end{tabular}



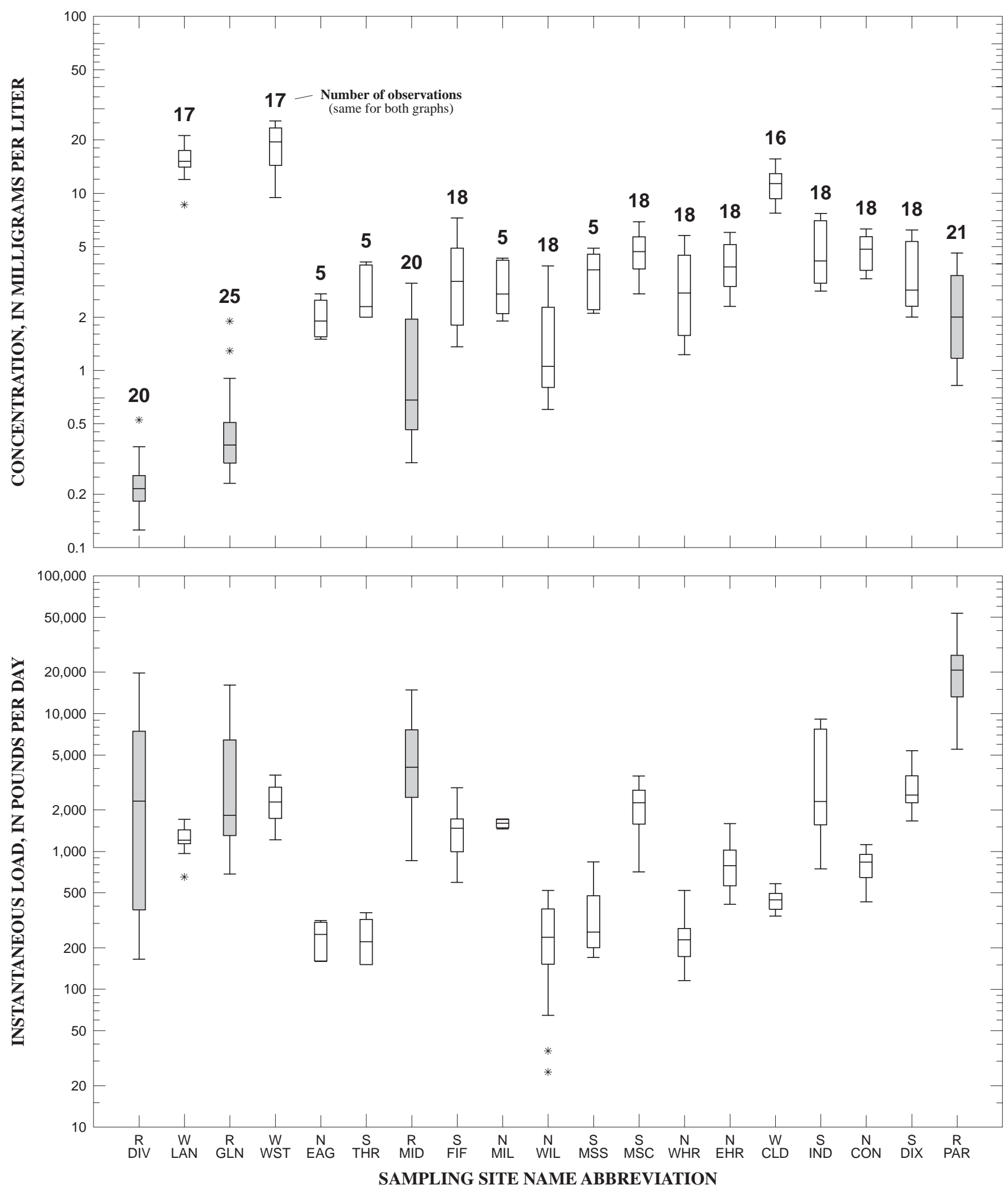

Figure 5. Instantaneous concentrations and daily loads of total nitrogen in samples from 19 sites in the lower Boise River Basin, May 1994 through February 1997. (Shaded boxes represent Boise River sites; see table 3 for sampling site name abbreviations) 
dahl nitrogen and includes ammonium), and dissolved nitrite plus nitrate. Total nitrogen was calculated as the sum of total ammonia plus organic nitrogen and dissolved nitrite plus nitrate. Dissolved nitrite plus nitrate was the dominant nitrogen species detected.

Median concentrations of total nitrogen among the 19 sampling sites ranged from $0.2 \mathrm{mg} / \mathrm{L}$ (Boise River below Diversion Dam) to $19.2 \mathrm{mg} / \mathrm{L}$ (West Boise WTF) (table 4, fig. 5). Four sites were sampled only 5 times, whereas the other sites were sampled between 17 and 25 times, so caution is advised when comparing median concentrations. Median concentrations of total nitrogen at the Boise River sites increased in a downstream direction and were $0.2 \mathrm{mg} / \mathrm{L}$ below Diversion Dam, $0.4 \mathrm{mg} / \mathrm{L}$ at Glenwood Bridge, $0.7 \mathrm{mg} / \mathrm{L}$ near Middleton, and $2.0 \mathrm{mg} / \mathrm{L}$ near Parma. Among the six northside tributary/drains, six southside tributary/drains, and three WTFs, median concentrations of total nitrogen were $2.9,3.5$, and $15.1 \mathrm{mg} / \mathrm{L}$, respectively. Results for inorganic nitrogen were similar to those for total nitrogen (fig. 6).

The daily load of total nitrogen at each site was computed using the instantaneous discharge and associated concentration of total nitrogen. Median daily loads of total nitrogen among the 19 sites ranged from $221 \mathrm{lb} / \mathrm{d}$ (Thurman Drain near Eagle) to 20,800 lb/d (Boise River near Parma) (fig. 5, table 4). Median daily loads of total nitrogen at the four Boise River sites decreased from Diversion Dam (2,320 lb/d) to Glenwood Bridge $(1,840$ $\mathrm{lb} / \mathrm{d})$, about doubled near Middleton (4,080 lb/d), and were $20,800 \mathrm{lb} / \mathrm{d}$ near Parma. Median daily loads of total nitrogen at three of the southside tributary/drains (Mason Creek at mouth, Indian Creek at mouth, and Dixie Drain at mouth) exceeded 2,000 lb/d, comparable to the 2,230-lb/d input from the West Boise WTF (table 4). Results for inorganic nitrogen were similar to those for total nitrogen (fig. 6).

Temporal trends in total nitrogen and dissolved inorganic nitrogen (fig. 7) in the Boise River near Parma were evaluated for the period June 1974 through February 1997. Data used prior to this study were from other USGS data collection programs. The LOWESS (LOcally WEighted Scatterplot Smoothing) technique was used to adjust concentrations on the basis of streamflow (Helsel and Hirsch, 1992). Streamflow adjustment eliminates trends caused solely by variations in streamflow. Thus, trends caused by variations in concentrations can be observed. Trends for total nitrogen and dissolved inorganic nitrogen do not appear to be affected by stream- flow adjustment. On the basis of the adjusted trend, total nitrogen concentrations declined slightly beginning in 1992, whereas dissolved inorganic nitrogen concentrations began declining sharply in 1994.

\section{Phosphorus}

Phosphorus, like nitrogen, is one of several essential nutrients in the metabolism of aquatic plants. Eutrophication research has focused heavily on phosphorus because it is the nutrient typically found to have the smallest supply-to-demand ratio for aquatic plant growth (Ryding and Rast, 1989). Forms of phosphorus in aquatic ecosystems commonly include $\mathrm{PO}_{4}$ (also called dissolved reactive phosphorus), hydrolyzable phosphorus, inorganic compounds, and organic compounds. Analyses reported for this study include total phosphorus, dissolved phosphorus, and dissolved orthophosphorus. The orthophosphate ion is especially important because it is directly available for metabolic use by aquatic plants. Dissolved orthophosphorus was the dominant phosphorus species detected.

Median concentrations of total phosphorus among the 19 sites ranged from $0.02 \mathrm{mg} / \mathrm{L}$ at Boise River below Diversion Dam to $6.60 \mathrm{mg} / \mathrm{L}$ at West Boise WTF (fig. 8, table 5). Median concentrations of total phosphorus at the four Boise River sites increased in a downstream direction-from $0.02 \mathrm{mg} / \mathrm{L}$ below Diversion Dam to $0.08 \mathrm{mg} / \mathrm{L}$ at Glenwood Bridge, nearly doubling to $0.15 \mathrm{mg} / \mathrm{L}$ near Middleton, and nearly doubling again to $0.27 \mathrm{mg} / \mathrm{L}$ near Parma. Among the six northside tributary/drains, six southside tributary/drains, and three WTFs, median concentrations of total phosphorus were $0.22,0.29$, and $4.9 \mathrm{mg} / \mathrm{L}$, respectively.

Median daily loads of total phosphorus among the 19 sites ranged from $9 \mathrm{lb} / \mathrm{d}$ at Thurman Drain near Eagle to 2,260 lb/d at Boise River near Parma (fig. 8, table 5). Median daily loads of total phosphorus at the four Boise River sites began at $101 \mathrm{lb} / \mathrm{d}$ below Diversion Dam, increased to $372 \mathrm{lb} / \mathrm{d}$ at Glenwood Bridge, nearly tripled to $946 \mathrm{lb} / \mathrm{d}$ near Middleton, and were 2,260 lb/d near Parma. Among the 15 sources of discharge to the Boise River, the West Boise WTF was the source of the largest median daily load of total phosphorus $(810 \mathrm{lb} / \mathrm{d})$; Dixie Drain was the source of the second-largest load (285 lb/d). Results for dissolved orthophosphorus (fig. 9) were similar to those for total phosphorus.

Temporal trends in total phosphorus and dissolved orthophosphorus (fig. 10) at the Boise River near Parma also were evaluated. Adjusting total phosphorus con- 

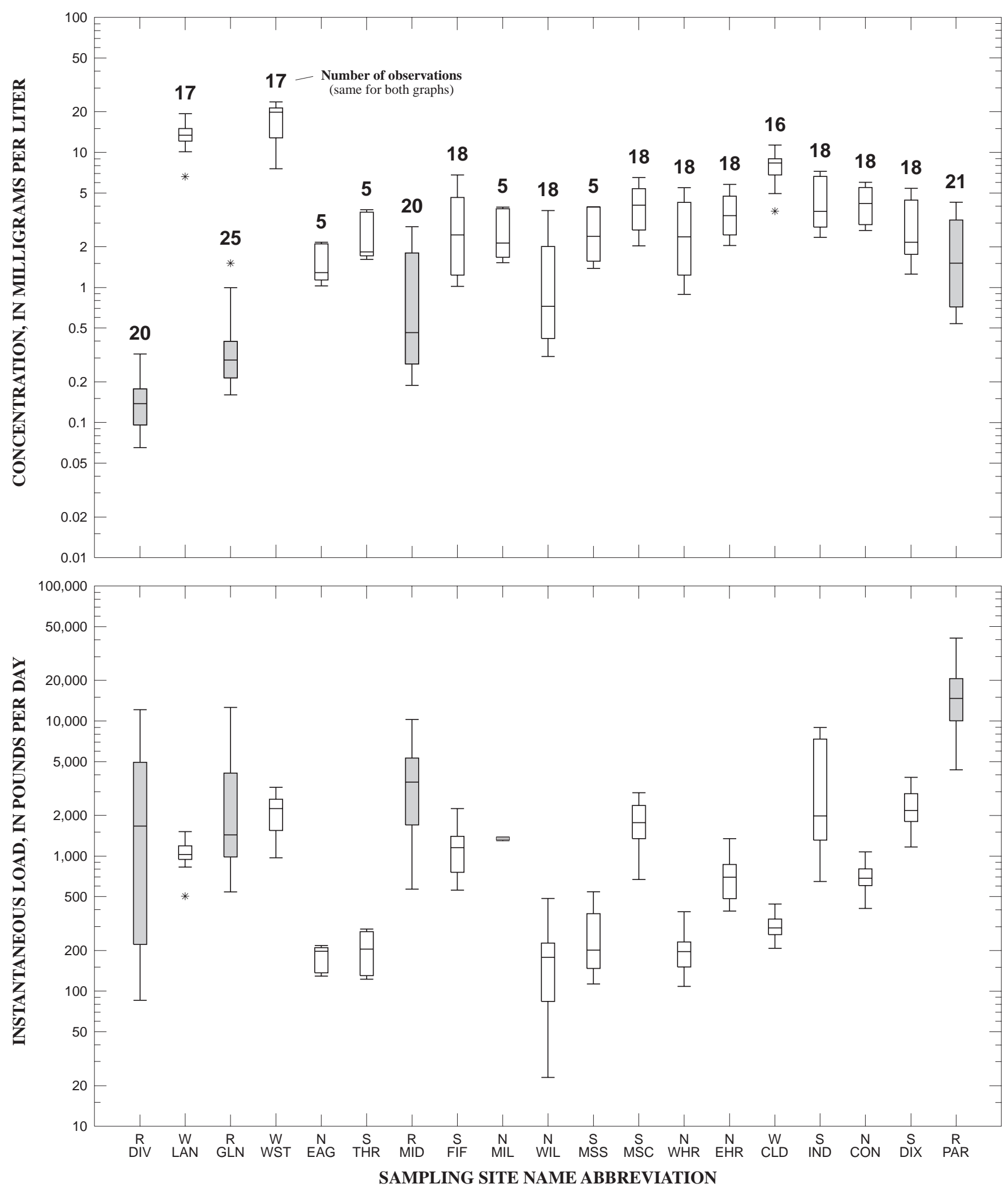

Figure 6. Instantaneous concentrations and daily loads of dissolved inorganic nitrogen in samples from 19 sites in the lower Boise River Basin, May 1994 through February 1997. (Shaded boxes represent Boise River sites; see table 3 for sampling site name abbreviations) 

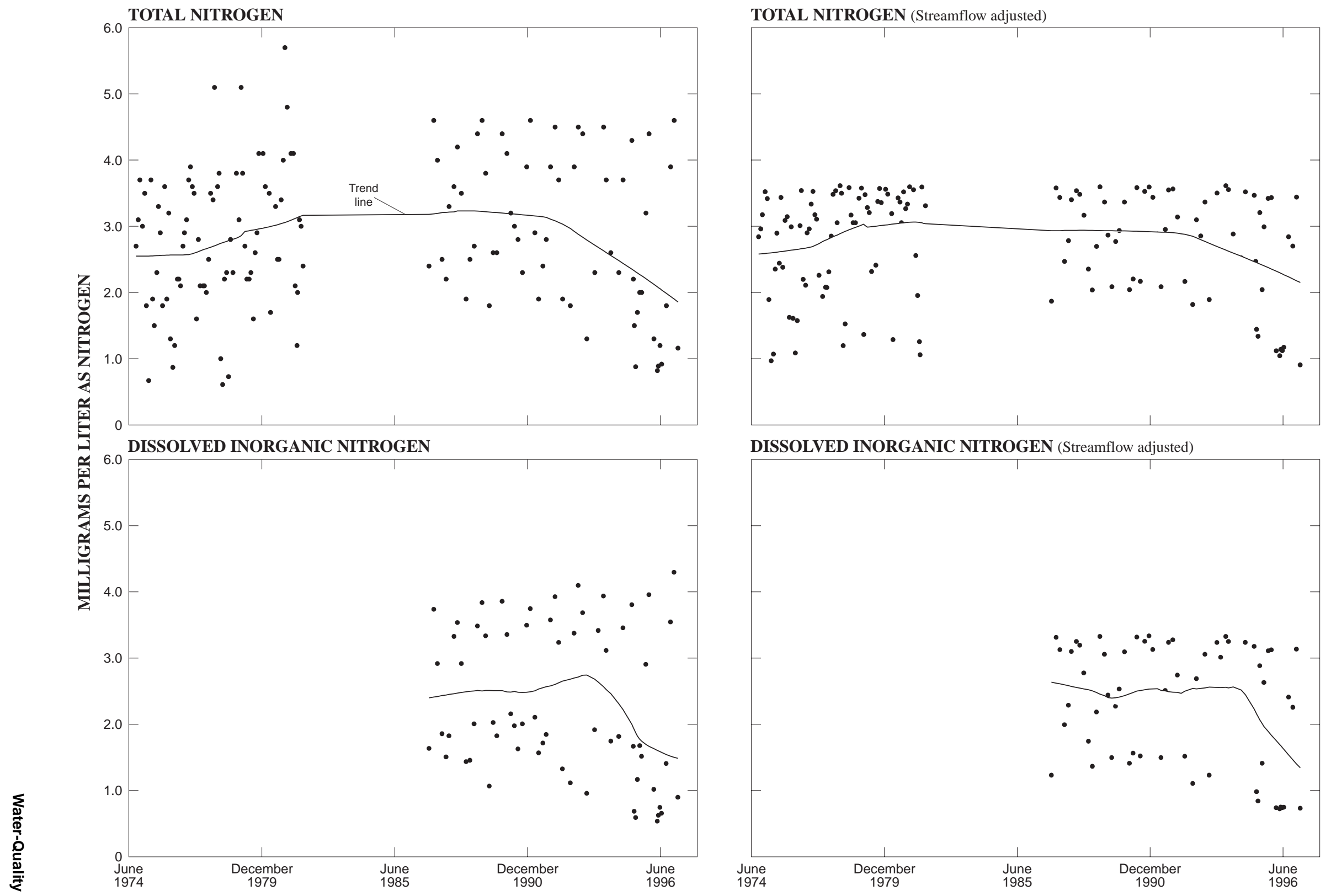

Figure 7. Time series and trend line of concentrations of total nitrogen and dissolved inorganic nitrogen in samples from the Boise River near Parma, June 1974 through February 1997. 

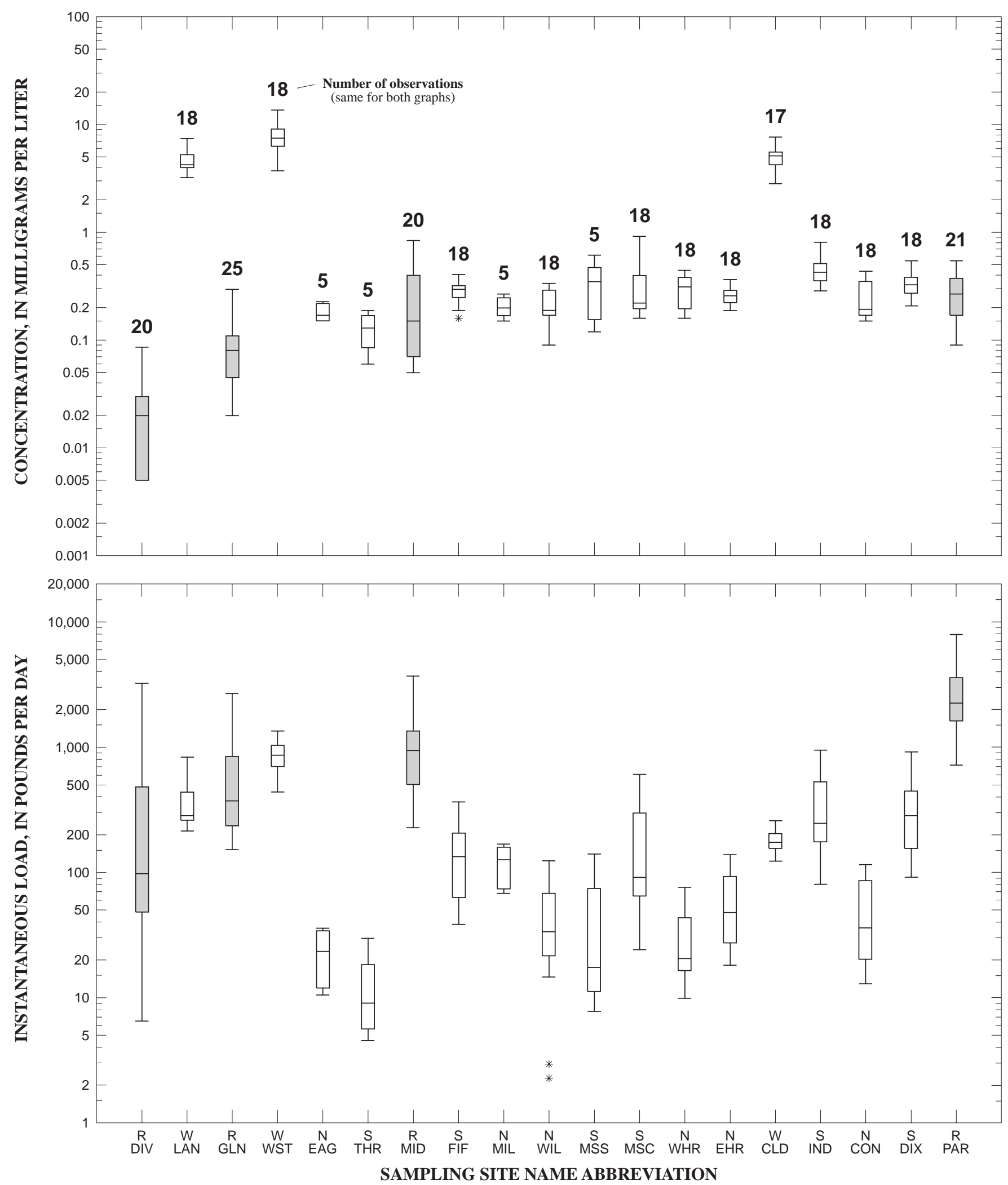

Figure 8. Instantaneous concentrations and daily loads of total phosphorus in samples from 19 sites in the lower Boise River Basin, May 1994 through February 1997. (Shaded boxes represent Boise River sites; see table 3 for sampling site name abbreviations) 
Table 5. Statistical summary of total phosphorus concentrations and instantaneous loads in samples from sites in the lower Boise River Basin, May 1994 through February 1997

[Sampling site locations are shown by reference number in figure 1 and are listed in table 3; P, phosphorus; WTF, wastewater treatment facility]

\begin{tabular}{|c|c|c|c|c|c|c|}
\hline \multirow{2}{*}{$\begin{array}{l}\text { Sampling } \\
\text { site } \\
\text { reference } \\
\text { number }\end{array}$} & \multirow[b]{2}{*}{ Site name } & \multirow{2}{*}{$\begin{array}{l}\text { Number } \\
\text { of } \\
\text { samples }\end{array}$} & \multicolumn{3}{|c|}{$\begin{array}{l}\text { Concentration or instantaneous } \\
\text { load at indicated percentile }\end{array}$} & \multirow{2}{*}{$\begin{array}{c}\text { Maximum } \\
\text { concentration or } \\
\text { instantaneous } \\
\text { load }\end{array}$} \\
\hline & & & 25 & 50 & 75 & \\
\hline \multicolumn{7}{|c|}{ Total phosphorus, milligrams per liter as $\mathbf{P}$} \\
\hline 1 & Boise River below Diversion Dam .... & 20 & 0.01 & 0.02 & 0.03 & 0.09 \\
\hline 3 & Lander Street WTF $\ldots \ldots \ldots \ldots \ldots \ldots$ & 18 & 3.50 & 3.70 & 4.60 & 6.50 \\
\hline 4 & Boise River at Glenwood Bridge. . . . . . & 25 & .05 & .08 & .11 & .30 \\
\hline 5 & West Boise WTF . . . . . . . . . . . & 18 & 5.52 & 6.60 & 8.00 & 12.00 \\
\hline 6 & Eagle Drain at Eagle $\ldots \ldots \ldots \ldots \ldots$ & 5 & .15 & .17 & .22 & .23 \\
\hline 7 & Thurman Drain near Eagle. . . . . . . . . & 5 & .09 & .13 & .17 & .19 \\
\hline 8 & Boise River near Middleton. . . . . . . . . . & 20 & .07 & .15 & .40 & .85 \\
\hline 9 & Fifteenmile Creek at mouth . . . . . . . . & 18 & .25 & .30 & .33 & .41 \\
\hline 10 & Mill Slough below Grade Ditch. ...... & 5 & .17 & .20 & .25 & .27 \\
\hline 11 & Willow Creek at Middleton . . . . . . . . . & 18 & .17 & .19 & .29 & .34 \\
\hline 12 & Mason Slough at mouth. . . . . . . . . & 5 & .16 & .35 & .49 & .62 \\
\hline 13 & Mason Creek at mouth. . . . . . . . . . . & 18 & .20 & .22 & .40 & .93 \\
\hline 14 & West Hartley Gulch near Caldwell .... & 18 & .20 & .31 & .39 & .45 \\
\hline 15 & East Hartley Gulch near Caldwell . . . . . & 18 & .23 & .26 & .29 & .37 \\
\hline 17 & Caldwell WTF . . . . . . . . . . . & 17 & 3.70 & 4.50 & 4.90 & 6.70 \\
\hline 18 & Indian Creek at mouth . . . . . . . . . . & 18 & .36 & .43 & .52 & .82 \\
\hline 19 & Conway Gulch at Notus. . . . . . . . . & 18 & .17 & .19 & .35 & .44 \\
\hline 20 & Dixie Drain at mouth . . . . . . . . . & 18 & .27 & .33 & .39 & .55 \\
\hline 21 & Boise River near Parma . . . . . . . . . . & 21 & .17 & .27 & .38 & .55 \\
\hline \multicolumn{7}{|c|}{ Total phosphorus, instantaneous load, pounds per day as $P$} \\
\hline 1 & Boise River below Diversion Dam .... & 20 & 48 & 101 & 483 & 3,250 \\
\hline 3 & Lander Street WTF . . . . . . . . . . . & 18 & 245 & 267 & 412 & 782 \\
\hline 4 & Boise River at Glenwood Bridge...... & 25 & 237 & 372 & 847 & 2,690 \\
\hline 5 & West Boise WTF ............... & 18 & 659 & 810 & 971 & 1,260 \\
\hline 6 & Eagle Drain at Eagle $\ldots \ldots \ldots \ldots \ldots$ & 5 & 12 & 23 & 34 & 36 \\
\hline 7 & Thurman Drain near Eagle. ......... & 5 & 6 & 9 & 21 & 30 \\
\hline 8 & Boise River near Middleton. . . . . . . . . & 20 & 505 & 946 & 1,350 & 3,710 \\
\hline 9 & Fifteenmile Creek at mouth . . . . . . . & 8 & 63 & 135 & 207 & 365 \\
\hline 10 & Mill Slough below Grade Ditch. ..... . & 5 & 74 & 127 & 159 & 169 \\
\hline 11 & Willow Creek at Middleton .......... & 18 & 22 & 34 & 68 & 124 \\
\hline 12 & Mason Slough at mouth. . . . . . . . . . & 5 & 12 & 17 & 90 & 141 \\
\hline 13 & Mason Creek at mouth. . . . . . . . . . & 18 & 65 & 92 & 299 & 607 \\
\hline 14 & West Hartley Gulch near Caldwell .... & 18 & 17 & 21 & 44 & 76 \\
\hline 15 & East Hartley Gulch near Caldwell . . . . . & 18 & 27 & 48 & 95 & 138 \\
\hline 17 & Caldwell WTF . . . . . . . . . . . & 17 & 146 & 164 & 192 & 242 \\
\hline 18 & Indian Creek at mouth . . . . . . . . & 18 & 175 & 247 & 529 & 944 \\
\hline 19 & Conway Gulch at Notus. . . . . . . . . & 18 & 20 & 36 & 89 & 115 \\
\hline 20 & Dixie Drain at mouth . . . . . . . . . & 18 & 156 & 285 & 449 & 918 \\
\hline 21 & Boise River near Parma . . . . . . . . . . . & 21 & 1,620 & 2,260 & 3,650 & 7,960 \\
\hline
\end{tabular}

centrations by streamflow removed much of the concentration variability and noticeable trend. The more pronounced effect of flow on total phosphorus concentrations is likely the result of an increase in particulate transport of total phosphorus during high streamflow. Streamflow-adjusted concentrations of total phosphorus showed little discernible trend over the course of the study; however, dissolved orthophosphorus concentrations began declining sharply in 1994.

\section{Nitrogen-to-Phosphorus Ratios}

Concentrations of nitrogen and phosphorus, as well as the ratio of their biologically available forms, can give an indication of which nutrient is potentially limiting to algal growth in a water body. Literature suggests that nuisance levels of algal growth in streams can occur if concentrations of inorganic nitrogen (the sum of ammonia, nitrite, and nitrate as nitrogen) and soluble 

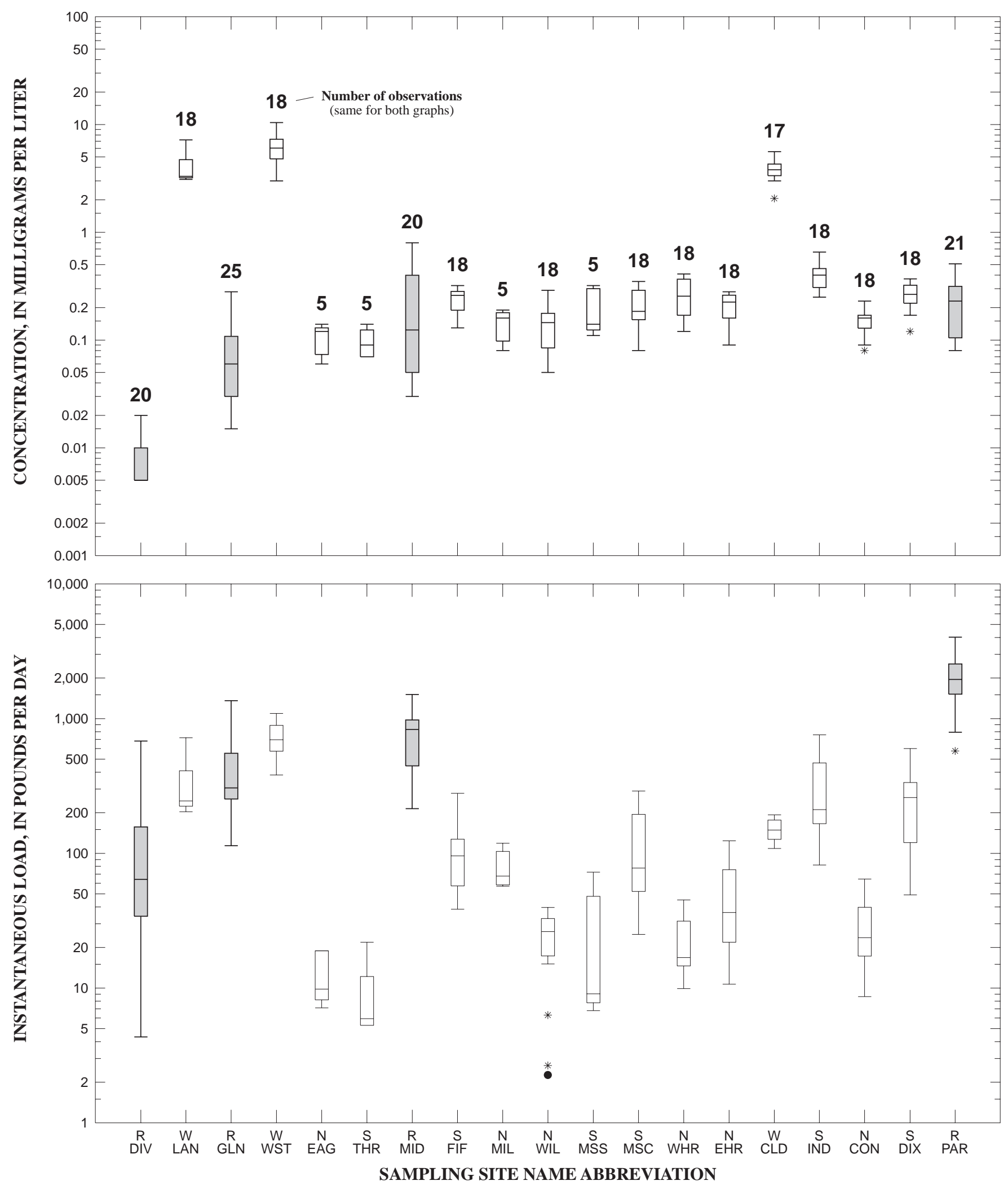

Figure 9. Instantaneous concentrations and daily loads of dissolved orthophosphorus in samples from 19 sites in the lower Boise River Basin, May 1994 through February 1997. (Shaded boxes represent Boise River sites; see table 3 for sampling site name abbreviations) 

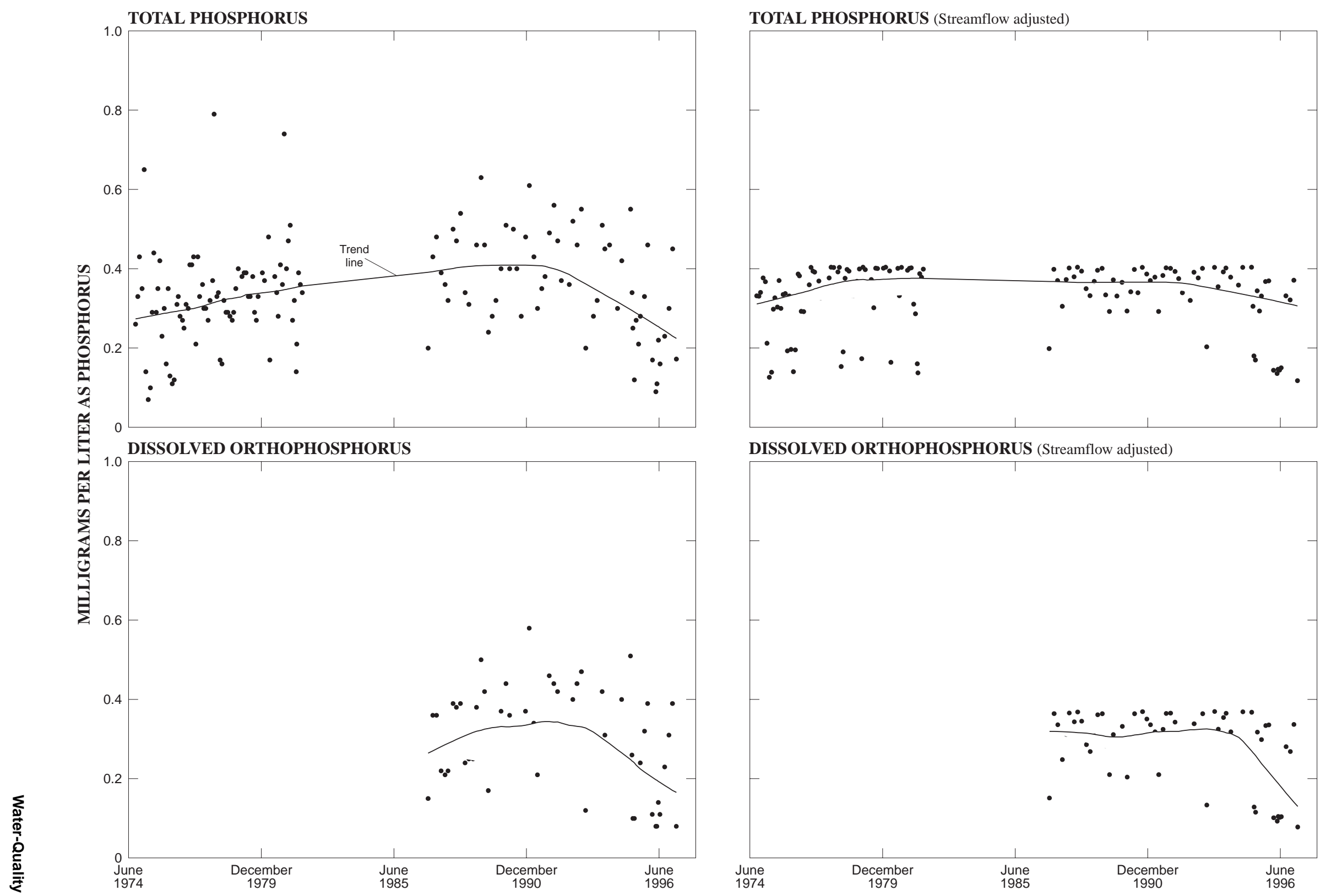

Figure 10. Time series and trend line of concentrations of total phosphorus and dissolved orthophosphorus in samples from the Boise River near Parma, June 1974 through February 1997. 
phosphorus exceed 0.3 and $0.01 \mathrm{mg} / \mathrm{L}$, respectively, at the start of the growing season (Sawyer, 1947, as cited in Mackenthun, 1969). Mackenthun (1969) recommended that total phosphorus concentrations in streams not exceed $0.1 \mathrm{mg} / \mathrm{L}$ in order to prevent nuisance levels of algal growth. In addition to their concentrations, the calculated mass ratio of dissolved inorganic nitrogen to dissolved orthophosphorus (N:P) can be compared to a preference ratio for algal uptake of $7.2 \mu \mathrm{g}$ of nitrogen per $1 \mu \mathrm{g}$ of phosphorus (7.2N:1P) (Ryding and Rast, 1989). If algal populations utilize nitrogen and phosphorus in this ideal ratio, any deviation from the ratio can be used as an additional tool to determine the potential for nutrient limitation. If $\mathrm{N}: \mathrm{P}$ is greater than 7.2, phosphorus is the potential limiting nutrient; if $\mathrm{N}: \mathrm{P}$ is less than 7.2, nitrogen is the potential limiting nutrient.

Only once did concentrations of inorganic nitrogen exceed $0.3 \mathrm{mg} / \mathrm{L}$, and never did concentrations of total phosphorus exceed $0.1 \mathrm{mg} / \mathrm{L}$ in water samples collected at the Diversion Dam site on the Boise River from May 1994 to February 1997. However, N:P greater than 7.2 in most of the water samples suggests a potential for phosphorus-limiting conditions at the Diversion Dam site (fig. 11). As nutrient concentrations increased downstream, N:P fell below 7.2 at the Glenwood and Middleton sites, and any potential phosphorus limitation in the river was eliminated. Inorganic nitrogen concentrations in water samples from Glenwood and Middleton were often smaller than $0.3 \mathrm{mg} / \mathrm{L}$ and, on the basis of the N:P, nitrogen could be limiting algal growth in that reach of the river during some parts of the year. At the Parma site, concentrations of inorganic nitrogen and total phosphorus were nearly always in excess of limiting concentrations, so algal growth did not appear to be limited by nutrient availability in that reach of the river.

\section{Suspended Sediment}

Suspended sediment is defined as "the velocityweighted concentration of suspended sediment in the sampled zone (from the water surface to a point approximately 0.3 feet above the bed) expressed as milligrams of dry sediment per liter of water-sediment mixture" (Brennan and others, 1996). The suspended sediment concentration, multiplied by the stream discharge, multiplied by 0.0027 yields suspended sediment discharge, expressed as tons per day.

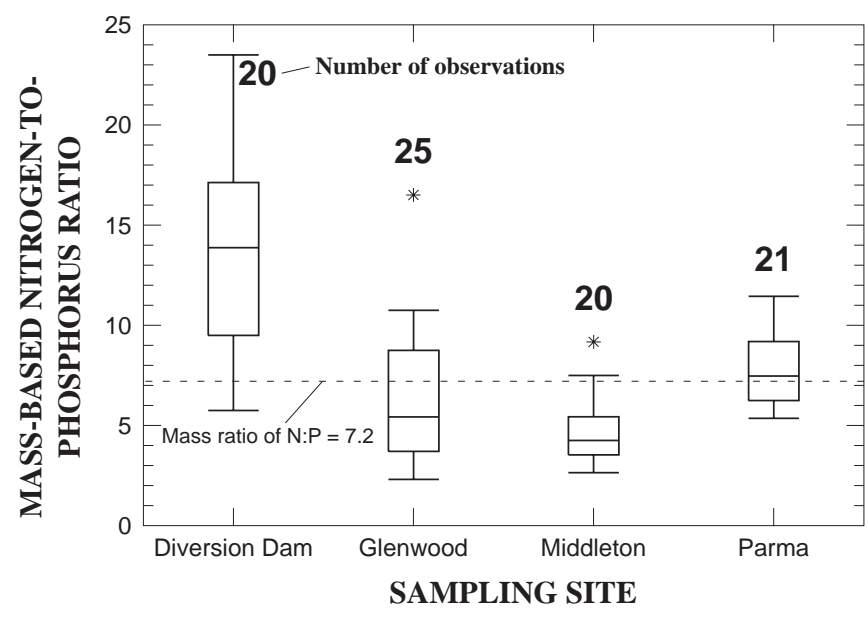

Figure 11. Mass ratios of dissolved inorganic nitrogen to dissolved orthophosphorus, grouped by Boise River sites, May 1994 through February 1997.

Median concentrations of suspended sediment among the 19 river and tributary/drain sites ranged from $5 \mathrm{mg} / \mathrm{L}$ at Boise River below Diversion Dam to $112 \mathrm{mg} / \mathrm{L}$ at Mason Slough at mouth (fig. 12, table 6). Median concentrations of suspended sediment at the four Boise River sites ranged from $5 \mathrm{mg} / \mathrm{L}$ below Diversion Dam, to $12 \mathrm{mg} / \mathrm{L}$ at Glenwood Bridge, decreased to $7 \mathrm{mg} / \mathrm{L}$ near Middleton, and increased to $47 \mathrm{mg} / \mathrm{L}$ near Parma. Among the six northside tributary/drains, six southside tributary/drains, and three WTFs, median concentrations of suspended sediment were 57, 67, and $9 \mathrm{mg} / \mathrm{L}$, respectively.

Median daily loads of suspended sediment among the 19 river and tributary/drain sites ranged from 0.42 ton/d at Thurman Drain near Eagle to 299 ton/d at Boise River near Parma (fig. 12, table 6). Median daily loads of suspended sediment at the four Boise River sites were 24.5 ton/d below Diversion Dam, decreased slightly to 23.6 ton/d at Glenwood Bridge, decreased further to 10 ton/d near Middleton, then increased to 299 ton/d near Parma. The reason for the decreasing trend in loads from Diversion Dam to Middleton is the diversion of water from the river between these sites during the irrigation season. Among the 15 sources of discharge to the Boise River, Dixie Drain was the source of the largest median daily load of suspended sediment (26.4 ton/d); Mason Creek was the source of the second-largest load (23.3 ton/d). 

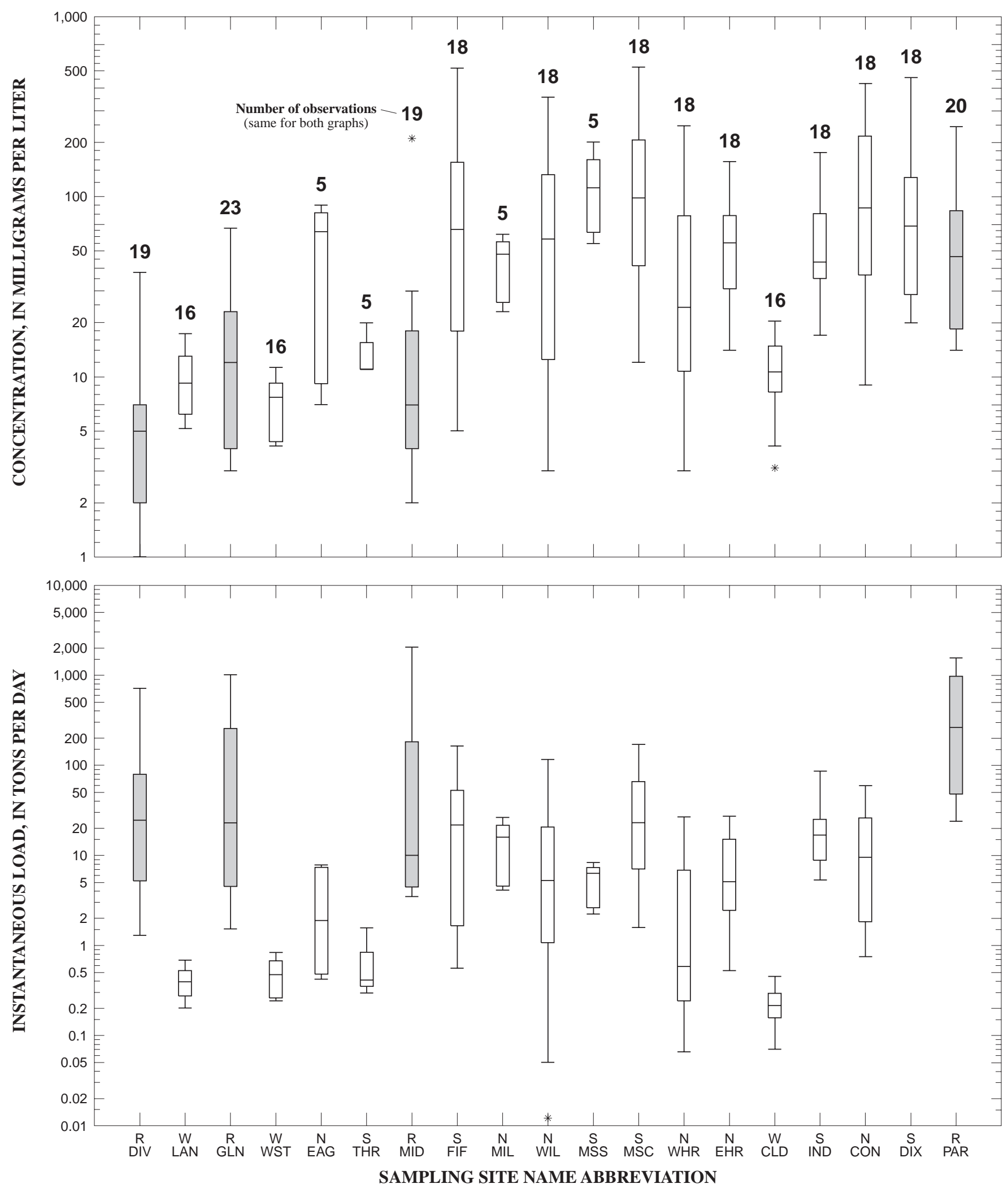

Figure 12. Instantaneous concentrations and daily loads of suspended sediment in samples from 19 sites in the lower Boise River Basin, May 1994 through February 1997. (Shaded boxes represent Boise River sites; see table 3 for sampling site name abbreviations) 
Table 6. Statistical summary of suspended sediment concentrations and instantaneous loads in samples from sites in the lower Boise River Basin, May 1994 through February 1997

[Sampling site locations are shown by reference number in figure 1 and are listed in table 3; WTF, wastewater treatment facility]

\begin{tabular}{|c|c|c|c|c|c|c|}
\hline \multirow{2}{*}{$\begin{array}{l}\text { Sampling } \\
\quad \text { site } \\
\text { reference } \\
\text { number }\end{array}$} & \multirow[b]{2}{*}{ Site name } & \multirow{2}{*}{$\begin{array}{c}\text { Number } \\
\text { of } \\
\text { samples }\end{array}$} & \multicolumn{3}{|c|}{$\begin{array}{l}\text { Concentration or instantaneous } \\
\text { load at indicated percentile }\end{array}$} & \multirow{2}{*}{$\begin{array}{c}\text { Maximum } \\
\text { concentration o } \\
\text { instantaneous } \\
\text { load }\end{array}$} \\
\hline & & & 25 & 50 & 75 & \\
\hline \multicolumn{7}{|c|}{ Suspended sediment, milligrams per liter } \\
\hline 1 & Boise River below Diversion Dam .... & 20 & 2 & 5 & 7 & 38 \\
\hline 3 & Lander Street WTF . . . . . . . . & 18 & 6 & 9 & 12 & 17 \\
\hline 4 & Boise River at Glenwood Bridge. . . . . . & 25 & 4 & 12 & 23 & 67 \\
\hline 5 & West Boise WTF . . . . . . . . . . . . . & 18 & 4 & 7 & 9 & 11 \\
\hline 6 & Eagle Drain at Eagle .... . & 5 & 9 & 64 & 82 & 90 \\
\hline 7 & Thurman Drain near Eagle ... & 5 & 11 & 11 & 16 & 20 \\
\hline 8 & Boise River near Middleton. . . . . . . . . & 20 & 4 & 7 & 18 & 211 \\
\hline 9 & Fifteenmile Creek at mouth. . . . . . . . & 18 & 18 & 66 & 156 & 518 \\
\hline 10 & Mill Slough below Grade Ditch ... & 5 & 26 & 48 & 57 & 62 \\
\hline 11 & Willow Creek at Middleton. . . . . . . . . & 18 & 13 & 59 & 133 & 357 \\
\hline 12 & Mason Slough at mouth. . . . . . . . . . & 5 & 64 & 112 & 165 & 202 \\
\hline 13 & Mason Creek at mouth $\ldots \ldots \ldots \ldots$ & 18 & 42 & 100 & 209 & 525 \\
\hline 14 & West Hartley Gulch near Caldwell . . . . & 18 & 11 & 25 & 79 & 248 \\
\hline 15 & East Hartley Gulch near Caldwell. . . . . & 18 & 31 & 55 & 79 & 157 \\
\hline 17 & Caldwell WTF. . . . . . . . . . . . & 17 & 8 & 11 & 14 & 20 \\
\hline 18 & Indian Creek at mouth . . . . . . . . & 18 & 35 & 43 & 81 & 176 \\
\hline 19 & Conway Gulch at Notus $\ldots \ldots \ldots \ldots$ & 18 & 37 & 89 & 217 & 425 \\
\hline 20 & Dixie Drain at mouth. . . . . . . . . . & 18 & 29 & 69 & 128 & 460 \\
\hline 21 & Boise River near Parma. . . . . . . . . . . & 21 & 19 & 47 & 84 & 245 \\
\hline \multicolumn{7}{|c|}{ Suspended sediment, instantaneous load, tons per day } \\
\hline 1 & Boise River below Diversion Dam .... . & 20 & 5.19 & 24.5 & 79.6 & 718 \\
\hline 3 & Lander Street WTF . . . . . . . . . & 18 & .26 & .38 & .50 & .66 \\
\hline 4 & Boise River at Glenwood Bridge. . . . . . & 25 & 4.54 & 23.6 & 258 & 1,020 \\
\hline 5 & West Boise WTF . . . . . . . . . . . . & 18 & .25 & .45 & .65 & .80 \\
\hline 6 & Eagle Drain at Eagle ....... & 5 & .48 & 1.9 & 7.40 & 7.78 \\
\hline 7 & Thurman Drain near Eagle . . . . . . . & 5 & .36 & .42 & 1.01 & 1.56 \\
\hline 8 & Boise River near Middleton. . . . . . . . . & 20 & 4.44 & 10.0 & 183 & 2,066 \\
\hline 9 & Fifteenmile Creek at mouth. . . . . . . . & 18 & 1.67 & 21.9 & 53.2 & 165 \\
\hline 10 & Mill Slough below Grade Ditch ..... . & 5 & 4.59 & 16.0 & 22.1 & 26.3 \\
\hline 11 & Willow Creek at Middleton. . . . . . . . . & 18 & 1.08 & 5.26 & 20.7 & 117 \\
\hline 12 & Mason Slough at mouth. . . . . . . . . . & 5 & 2.67 & 6.34 & 7.40 & 8.27 \\
\hline 13 & Mason Creek at mouth $\ldots \ldots \ldots \ldots$ & 18 & 7.10 & 23.3 & 66.2 & 171 \\
\hline 14 & West Hartley Gulch near Caldwell .... & 18 & .24 & .59 & 6.85 & 26.8 \\
\hline 15 & East Hartley Gulch near Caldwell. . . . . & 18 & 2.63 & 5.37 & 15.2 & 27.10 \\
\hline 17 & Caldwell WTF . . . . . . . . . . & 17 & .15 & .21 & .28 & .43 \\
\hline 18 & Indian Creek at mouth. . . . . . . . . & 18 & 8.91 & 16.8 & 25.2 & 86.6 \\
\hline 19 & Conway Gulch at Notus $\ldots \ldots \ldots \ldots$ & 18 & 1.83 & 9.52 & 26.1 & 59.6 \\
\hline 20 & Dixie Drain at mouth. . . . . . . . . & 18 & 10.30 & 26.4 & 60.3 & 459 \\
\hline 21 & Boise River near Parma . . . . . . . . . . & 21 & 48.50 & 299 & 978 & 1,565 \\
\hline
\end{tabular}

Temporal trends in suspended sediment (fig. 13) in the Boise River near Parma also were evaluated. The streamflow-adjusted trend for suspended sediment was similar to the unadjusted trend, thereby indicating a lack of strong influence by streamflow on the trend. Streamflow-adjusted concentrations of suspended sediment showed little discernible trend over the course of the study.

\section{Nitrogen and Phosphorus Loads}

Nitrogen and phosphorus loads entering the Boise River between the Diversion Dam and Parma were estimated using measurements of discharge and nutrients made at the four main-stem river sites, six northside tributary/drains, six southside tributary/drains, and three WTFs. Measurements were made during 1-week 


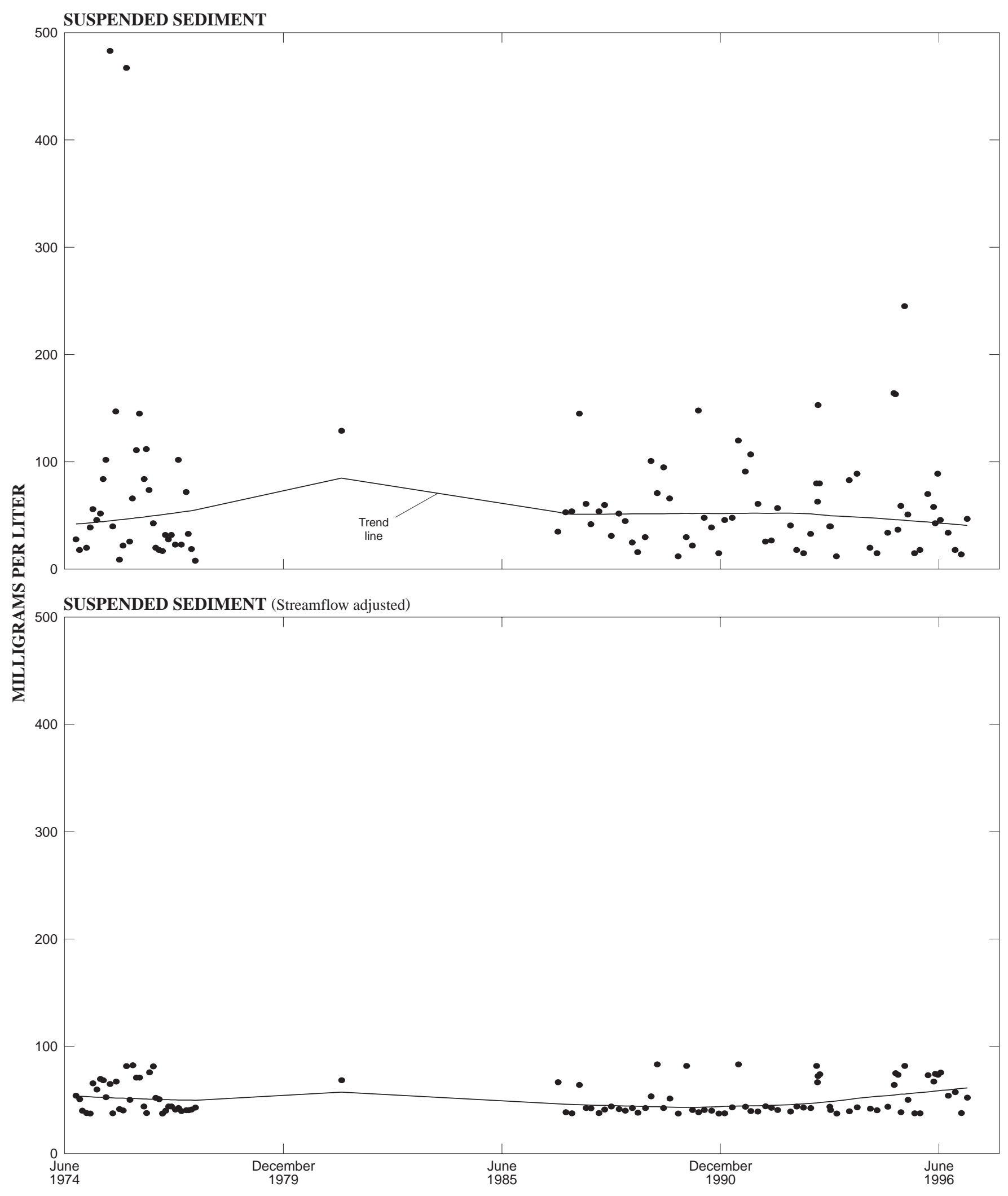

Figure 13. Time series and trend line of concentrations of suspended sediment in samples from the Boise River near Parma, June 1974 through February 1997. 
rounds in each of four synoptic sampling periods: May 1995 and May 1996 (irrigation, or high-flow, season) and November 1994 and December 1995 (post-irrigation, or low-flow, season). The discharge and nutrient loads measured at the 15 tributary/drains and WTFs were compared with the differences in discharge and loads measured in the Boise River between the Diversion Dam and Parma (fig. 14).

In general, loads of total nitrogen and total phosphorus entering the river from tributary/drains and WTFs were similar to the differences in loads measured at the Diversion Dam and Parma. However, because water is diverted from the river during the irrigation season, comparisons between discharge and nutrient loads entering the river at all measured sites during the highflow sampling periods could be misleading. Diversions from the Boise River during the May 1995 and May 1996 sampling periods account for the loss of discharge between the Diversion Dam and Parma, as indicated in figure 14. During the May 1995 sampling period, there was less water in the Boise River at Parma site than at the Diversion Dam site. A more accurate comparison between discharge and nutrient loads entering the river at measured sites could be made if samples were collected from the diversions, as well as from tributary/ drains. During the post-irrigation season, water is not diverted from the Boise River, and nutrient loads can be compared directly with discharge.

During the post-irrigation (low-flow) season, discharge measured at the tributary/drains and WTFs constituted about 80 percent of the discharge in the Boise River between Diversion Dam and Parma. Unmeasured ground-water inflow probably constituted most of the remaining 20 percent. Nitrogen and phosphorus loads measured at the tributary/drains and WTFs during lowflow sampling were near, or exceeded, the loads in the Boise River between Diversion Dam and Parma. Loss of nitrogen and phosphorus once these nutrients enter the river probably is attributable to biotic uptake, partitioning, and sedimentation. Southside tributary/drains contributed most of the discharge and total nitrogen to the Boise River during the low-flow sampling periods; WTFs contributed most of the total phosphorus.

Although the total measured discharge entering the Boise River from tributary/drains and WTFs was substantially larger during high-flow sampling than during low-flow sampling, the nitrogen and phosphorus loads were not. Total nitrogen and total phosphorus loads were relatively constant in discharge from WTFs during all four sampling periods and were only slightly larger in discharge from the northside tributary/drains during the high-flow sampling periods. Total nitrogen and total phosphorus loads from the southside tributary/drains did not correlate well with the season; the total nitrogen load from southside tributary/drains was largest during the December 1995 period, and the total phosphorus load was largest during the May 1996 period.

\section{Selected Water-Quality Constituents}

\section{DISSOLVED OXYGEN}

The concentration of dissolved oxygen in surface water is a measure of the amount of unbound oxygen and is affected by temperature, barometric pressure, biological processes (photosynthesis, respiration, and decomposition of organic material) and stream mixing.

State of Idaho water-quality standards specify "dissolved oxygen concentrations exceeding $6 \mathrm{mg} / \mathrm{L}$ at all times" (Idaho Department of Health and Welfare, 1993). State water-quality standards further specify that "The waters of the Boise River from Veterans State Park to its mouth will have dissolved oxygen concentrations of six (6) $\mathrm{mg} / \mathrm{L}$ or seventy-five percent $(75 \%)$ of saturation, whichever is greater, during the spawning period of salmonid fishes inhabiting those waters" (Idaho Department of Health and Welfare, 1993). Dissolved oxygen concentrations ranged from $6.9 \mathrm{mg} / \mathrm{L}$ in the Boise River near Parma on August 16, 1995, to 14.8 mg/L in Fifteenmile Creek on February 13, 1997. No dissolved oxygen concentrations violated State standards. Statistical characteristics of dissolved oxygen measured at river and tributary/drain sites in the lower Boise River Basin from May 1994 through February 1997 are summarized in figure 15.

\section{pH}

The water-quality variable $\mathrm{pH}$ represents the negative base-10 log of the hydrogen-ion activity in moles per liter (Hem, 1985). The $\mathrm{pH}$ scale ranges from 0 to 14 standard units; at neutrality, $\mathrm{pH}$ equals 7 . Values of $\mathrm{pH}$ less than 7 are considered acidic, and values greater than 7 are considered basic. Unpolluted river water generally has a pH within the range 6.5 to 8.5 (Hem, 1985).

State of Idaho water-quality standards for $\mathrm{pH}$ for coldwater biota specify "hydrogen ion concentration $(\mathrm{pH})$ values within the range of six point five (6.5) to 

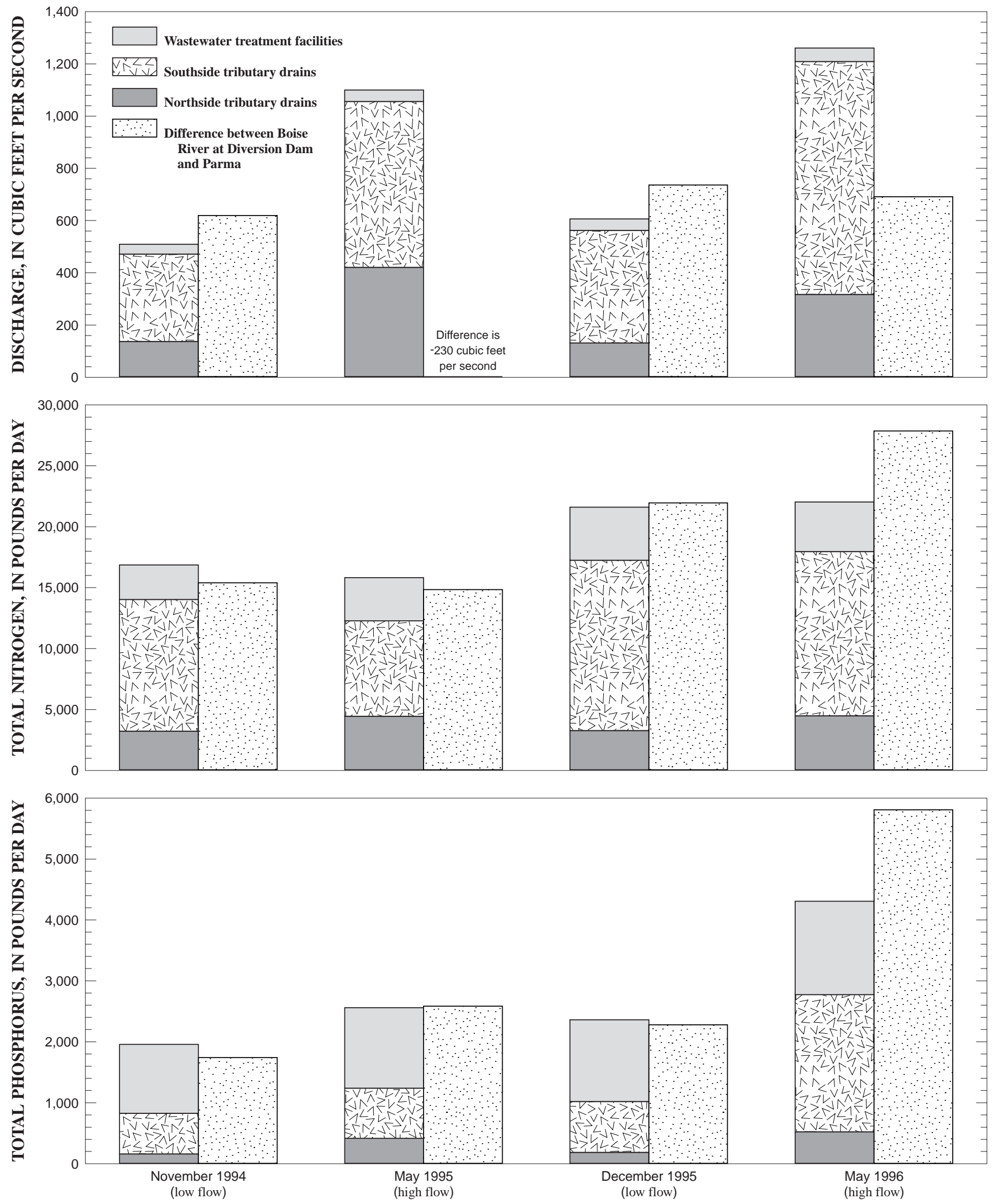

Figure 14. Discharge and nutrient loads entering the Boise River from wastewater treatment facilities and tributary/drains during four synoptic sampling rounds, November 1994 through May 1996. 

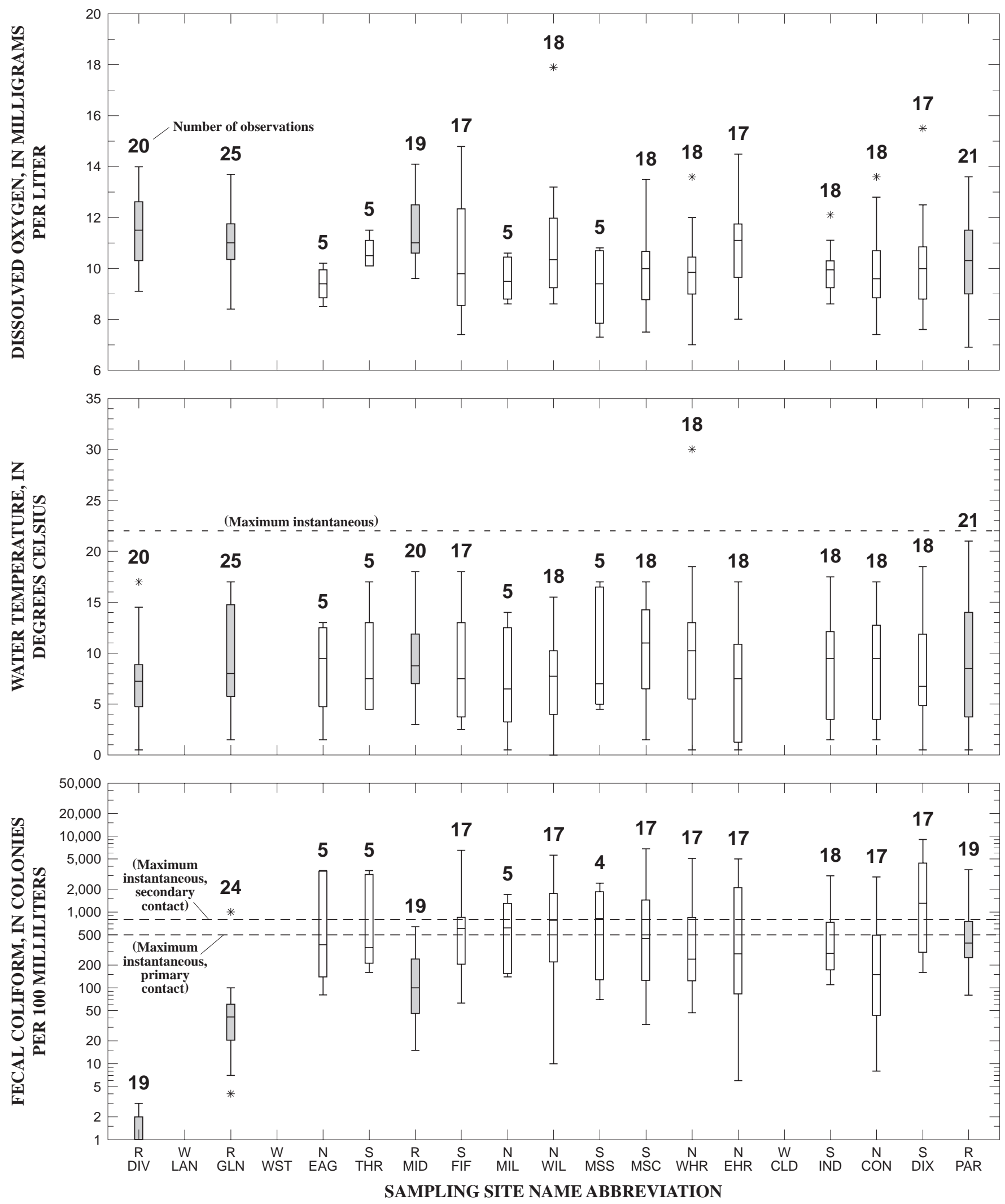

Figure 15. Concentrations of selected water-quality constituents in samples from 16 sites in the lower Boise River Basin, May 1994 through February 1997. (Shaded boxes represent Boise River sites; see table 3 for sampling site name abbreviations) 
nine point five (9.5)" (Idaho Department of Health and Welfare, 1993). Values of $\mathrm{pH}$ ranged from 6.6 in the Boise River below Diversion Dam on August 21, 1996, to 8.9 in the Boise River near Parma on March 21, 1995 (Brennan and others, 1996, 1997). No pH values violated State standards.

\section{SPECIFIC CONDUCTANCE}

Specific conductance, a measure of electrical conductivity in water, is generally proportional to the concentration of total dissolved solids. Surface water has a wide range of specific conductance values, ranging from about $50 \mu \mathrm{S} / \mathrm{cm}$ in freshwater to about $50,000 \mu \mathrm{S} / \mathrm{cm}$ in seawater (Hem, 1985). Specific conductance values ranged from $59 \mu \mathrm{S} / \mathrm{cm}$ in the Boise River below Diversion Dam on June 12, 1996, to $845 \mu \mathrm{S} / \mathrm{cm}$ in Dixie Drain on February 11, 1997 (Brennan and others, 1996, 1997).

\section{WATER TEMPERATURE}

Water temperature is an important consideration for aquatic biota. State of Idaho water-quality standards for coldwater biota specify "water temperatures of twentytwo (22) degrees $\mathrm{C}$ or less with a maximum daily average of no greater than nineteen (19) degrees C" (Idaho Department of Health and Welfare, 1993). A statistical summary of water temperatures measured at river and tributary/drain sites in the lower Boise River Basin from May 1994 through February 1997 is shown in figure 15.

Daily mean water temperature data over a 50-day period between July 18 and September 5, 1996, collected using Hobo continuous temperature recorders, are plotted in figure 16. The State of Idaho standard for coldwater biota was exceeded by 34 percent at Middleton, 48 percent at Caldwell, and 80 percent near Parma.

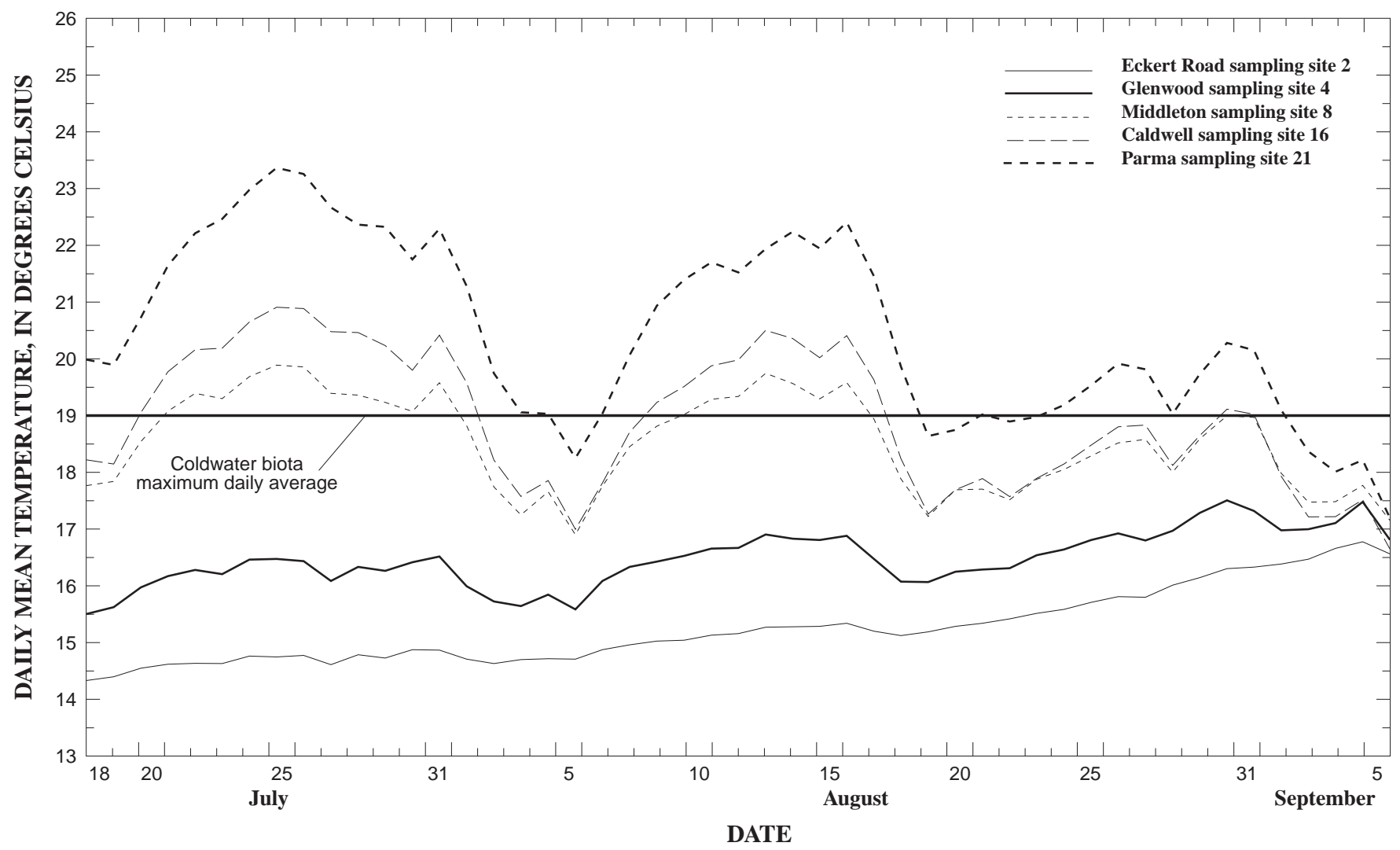

Figure 16. Daily mean water temperatures at five Boise River sites between July 18 and September 5, 1996. 


\section{FECAL COLIFORM BACTERIA}

Fecal coliform bacteria counts, expressed as number of colonies per $100 \mathrm{~mL}$ of water, are useful in determining the probability of harmful levels of pathogens in water and for classifying the suitability of that water for primary and secondary contact recreation and other uses. State of Idaho water-quality standards specify that "waters designated for primary contact recreation are not to contain fecal coliform bacteria significant to the public health in concentrations exceeding 500/100 mL at any time" $(800 / 100 \mathrm{~mL}$ standard for secondary contact recreation; Idaho Department of Health and Welfare, 1993). Violations of State standards for primary and secondary contact recreation were observed at all tributary/drains and in the Boise River near Parma. Median instantaneous concentrations of fecal coliform bacteria exceeded State standards for primary contact recreation at five tributary/drains and exceeded standards for secondary contact recreation at one tributary/ drain (Dixie Drain). Fecal coliform bacteria concentrations at river and tributary/drain sites are summarized in figure 15.

\section{SUMMARY}

Agricultural land and water use, wastewater treatment facility (WTF) discharges, land development, road construction, urban runoff, confined-animal feeding operations, reservoir operation, and river channelization affect the water quality and biotic integrity of the lower Boise River. The U.S. Geological Survey began a comprehensive water-quality and biotic integrity assessment of the river in 1994. This study, being conducted in three phases, is designed to describe water quality of the lower Boise River and its tributaries and drains, assess the biotic integrity of the river, and monitor the longterm trends in water quality and biotic integrity of the river.

Phases 1 and 2 of the study consisted of 5 synoptic and 13 interval sampling rounds to determine major sources, concentrations, and relative loads of nutrients and suspended sediment entering the Boise River from its major tributary/drains and from WTFs.

In the Boise River, median concentrations of total nitrogen increased downstream, ranging from 0.2 milligrams per liter (mg/L) below Diversion Dam to $2.0 \mathrm{mg} / \mathrm{L}$ near Parma. The largest median concentration measured was $19.2 \mathrm{mg} / \mathrm{L}$ at the West Boise WTF. Median daily loads of total nitrogen in the Boise River ranged from 1,840 pounds per day $(\mathrm{lb} / \mathrm{d})$ at Glenwood Bridge to $20,800 \mathrm{lb} / \mathrm{d}$ near Parma. Median daily loads of total nitrogen in tributary/drains ranged from $221 \mathrm{lb} / \mathrm{d}$ at Thurman Drain to 2,570 lb/d at Dixie Drain. Three of the southside tributary/drains and one WTF contributed a median daily load of more than 2,000 lb/d. Trend analysis using LOcally WEighted Scatterplot Smoothing (LOWESS) techniques indicated that total nitrogen concentrations in the Boise River declined slightly beginning in 1992, whereas dissolved inorganic nitrogen began declining sharply in 1994.

Median concentrations of total phosphorus in the Boise River also increased downstream, ranging from $0.02 \mathrm{mg} / \mathrm{L}$ below Diversion Dam to $0.27 \mathrm{mg} / \mathrm{L}$ near Parma. The largest median concentration measured was $6.60 \mathrm{mg} / \mathrm{L}$ at the West Boise WTF. Median daily loads of total phosphorus in the Boise River ranged from $101 \mathrm{lb} / \mathrm{d}$ below Diversion Dam to 2,260 lb/d near Parma. Median daily loads of total phosphorus in tributary/drains ranged from $9 \mathrm{lb} / \mathrm{d}$ at Thurman Drain to $285 \mathrm{lb} / \mathrm{d}$ at Dixie Drain. Among the 15 sources of discharge to the Boise River, the West Boise WTF contributed the largest median daily load of total phosphorus (810 lb/d); Dixie Drain contributed the second-largest load $(285 \mathrm{lb} / \mathrm{d})$. Trend analysis using LOWESS techniques indicated little discernible trend in total phosphorus concentrations in the Boise River, whereas dissolved orthophosphorus began declining sharply in 1994.

Nitrogen-to-phosphorus ratios at the four river sites were calculated to ascertain which nutrient might be limiting algal growth at each site. If algal populations are assumed to utilize inorganic nitrogen and soluble phosphorus in the ratio $7.2 \mathrm{~N}: 1 \mathrm{P}$, phosphorus could be limiting algal growth at the Diversion Dam site, whereas nitrogen could be limiting algal growth at the Glenwood and Middleton sites during some parts of the year. Algal growth in the Boise River near Parma did not appear to be nutrient limited.

In the Boise River, median concentrations of suspended sediment increased downstream, ranging from $5 \mathrm{mg} / \mathrm{L}$ below Diversion Dam to $47 \mathrm{mg} / \mathrm{L}$ near Parma. The largest median concentration measured was $112 \mathrm{mg} / \mathrm{L}$ in Mason Slough. Median daily loads of suspended sediment in the Boise River ranged from 23.6 tons per day (ton/d) near Glenwood Bridge to 299 ton/d near Parma. Median daily loads of suspended sediment in tributary/drains ranged from 0.42 ton/d at Thurman Drain to 26.4 ton/d at Dixie Drain. Three of 
the southside tributary/drains contributed median daily loads of more than 20 ton/d. Trend analysis using LOWESS techniques indicated little discernible trend in suspended sediment concentrations in the Boise River.

Nitrogen and phosphorus loads entering the Boise River between Diversion Dam and Parma were estimated using measurements of discharge and nutrients made at the four main-stem river sites, six northside tributary/drains, six southside tributary/drains, and three WTFs. During low-flow sampling periods, discharge measured at the tributary/drains and WTFs constituted about 80 percent of the discharge in the Boise River between Diversion Dam and Parma. Unmeasured ground-water inflow probably constituted most of the remaining 20 percent. Nitrogen and phosphorus loads measured at the tributary/drains and WTFs during lowflow sampling were near, or exceeded, the loads in the Boise River between Diversion Dam and Parma. Loss of nitrogen and phosphorus once these nutrients enter the river probably is attributable to biotic uptake, partitioning, and sedimentation. Southside tributary/drains contributed most of the discharge and total nitrogen to the Boise River during the low-flow sampling periods; WTFs contributed most of the total phosphorus.

Concentrations of dissolved oxygen and values of pH during May 1994 through February 1997 did not violate State standards. Maximum daily mean water temperatures collected during a 50-day period between July 18 and September 5, 1996, exceeded the Idaho State standard for coldwater biota by 34 percent at Middleton, 48 percent at Caldwell, and 80 percent near Parma.

Median instantaneous concentrations of fecal coliform bacteria exceeded State standards for primary and secondary contact recreation at all tributary/drains and in the Boise River near Parma. Median concentrations exceeded State standards for primary contact recreation at five tributary/drains and exceeded standards for secondary contact recreation at one tributary/drain (Dixie Drain).

\section{REFERENCES CITED}

Brennan, T.S., O'Dell, I., Lehmann, A.K., and Tungate, A.M., 1996, Water Resources Data-Idaho, water year 1995, v. 2, Upper Columbia River Basin and Snake River Basin below King Hill: U.S. Geological Survey Water-Data Report ID-95-2, 357 p.
Brennan, T.S., Lehmann, A.K., O'Dell, I., and Tungate, A.M., 1997, Water resources data-Idaho, water year 1996, v. 2, Upper Columbia River Basin and Snake River Basin below King Hill: U.S. Geological Survey Water-Data Report ID-96-2, 377 p.

Britton, L.J., and Greeson, P.E., eds., 1987, Methods for collection and analysis of aquatic biological and microbiological samples: U.S. Geological Survey Techniques of Water-Resources Investigations, book 5, chap. A4, $363 \mathrm{p}$.

Buchanan, T.J., and Somers, W.P., 1969, Discharge measurements at gaging stations: U.S. Geological Survey Techniques of Water-Resources Investigations, book 3, chap. A8, 65 p.

Bureau of Reclamation, 1977, Water quality study, Boise valley, v. 2: Bureau of Reclamation, 117 p.

Clark, W.H., and Bauer, S.B., 1983, Water quality status report, lower Boise River drains, Canyon County, Idaho: Idaho Department of Health and Welfare, Division of Environment, Water Quality Series no. 50, $101 \mathrm{p}$.

Edwards, T.K., and Glysson, G.D., 1998, Field methods for measurement of fluvial sediment: U.S. Geological Survey Techniques of Water Resources Investigations, Book 3, Chap. C2, 80 p.

Fishman, M.J., 1993, Methods of analysis by the U.S. Geological Survey National Water Quality Laboratorydetermination of inorganic and organic constituents in water and fluvial sediments: U.S. Geological Survey Open-File Report 93-125, 217 p.

Friedman, L.C., and Erdmann, D.E., 1982, Quality assurance practices for the chemical and biological analyses of water and fluvial sediments: U.S. Geological Survey Techniques of Water-Resources Investigations, book 5, chap. A6, $181 \mathrm{p}$.

Guy, H.P., 1969, Laboratory theory and methods for sediment analysis: U.S. Geological Survey Techniques of WaterResources Investigations, book 5, chap. C1, 58 p.

Helsel, D.R., and Hirsch, R.M., 1992, Statistical methods in water resources: New York, Elsevier, 522 p.

Hem, J.D., 1985, Study and interpretation of the chemical characteristics of natural water ( $3 \mathrm{~d}$ ed.): U.S. Geological Survey Water-Supply Paper 2254, 264 p.

Idaho Department of Health and Welfare, 1989, Idaho water quality status report and nonpoint source assessment 1988: Idaho Department of Health and Welfare, Division of Environmental Quality, variously paged. 1992, The 1992 Idaho water quality status report: Idaho Department of Health and Welfare, Division of Environmental Quality, variously paged.

-1993, Idaho water quality standards and wastewater treatment requirements: Boise, Idaho Depart-ment of Health and Welfare.

Ingham, M., 1993, Conway Gulch, Canyon County, Idaho, 1958-1989: Idaho Department of Health and Welfare, 
Division of Environmental Quality, State Agricultural Water Quality Program Water Quality Status Report no. $104,76 \mathrm{p}$.

Kjelstrom, L.C., 1995, Data for and adjusted regional regression models of volume and quality of urban storm-water runoff in Boise and Garden City, Idaho, 1993-94: U.S. Geological Survey Water-Resources Investigations Report 95-4228, 36 p.

Mackenthun, K.M., 1969, The practice of water pollution biology: U.S. Department of the Interior, Federal Water Pollution Control Administration, Divi-sion of Technical Support, $281 \mathrm{p}$.

Nace, R.L., West, S.W., and Mower, R.W., 1957, Feasibility of ground-water features of the alternate plan for the Mountain Home Project, Idaho: U.S. Geological Survey Water-Supply Paper 1376, 121 p.

Naylor, D.V., Lewis, G.C., Busch, J.R., and Fitzsimmons, D.W., 1976, Quality of irrigation and drainage waters in the Boise Valley: Moscow, Agricul-tural Experiment Station, University of Idaho, College of Agriculture, $22 \mathrm{p}$.

Pritt, J.W., and Raese, J.W., eds., 1995, Quality assurance/ quality control manual: National Water Quality Laboratory, U.S. Geological Survey Open-File Report 95-443, $35 \mathrm{p}$.
Ryding, S.O., and Rast, Walter, eds., 1989, The control of eutrophication of lakes and reservoirs, v. 1 of Programme on man and the biosphere series: Cambridge University Press, 295 p.

Shelton, L.R., 1994, Field guide for collecting and processing stream-water samples for the National Water-Quality Assessment Program: U.S. Geological Survey OpenFile Report 94-455, $42 \mathrm{p}$

Thomas, C.A., and Dion, N.P., 1974, Characteristics of streamflow and ground-water conditions in the Boise River Valley, Idaho: U.S. Geological Survey WaterResources Investigations Report 38-74, 56 p.

U.S. Environmental Protection Agency, 1994, List of waters still requiring total maximum daily loads (TMDLs) paragraph 303(d) list for the State of Idaho Decision Document, October 7, 1994, 13 p. plus app.

Warnick, C.C., and Brockway, C.E., 1974, Hydrology support study for a case study on a water and related land resources project, Boise Project, Idaho and Oregon: Moscow, Idaho Water Resources Research Institute, University of Idaho, Research Report OWRT Title II Contract C-4202. 